\title{
Normal fault growth and linkage in the Gediz (Alaşehir) Graben, Western Turkey, revealed by transient river long-profiles and slope-break knickpoints
}

DOI:

10.1002/esp.4049

\section{Abstract}

The Gediz (Alaşehir) Graben is located in the highly tectonically active and seismogenic region of Western Turkey. The rivers upstream of the normal fault-bounded graben each contain a non-lithologic knickpoint, including those that drain through inferred fault segment boundaries. Knickpoint heights measured vertically from the fault scale with footwall relief and documented fault throw (vertical displacement). Consequently, we deduce these knickpoints were initiated by an increase in slip rate on the basin-bounding fault, driven by linkage of the three main fault segments of the high-angle graben bounding fault array. Fault interaction theory and ratios of channel steepness suggest that the slip rate enhancement factor on linkage was a factor of 3. We combine this information with geomorphic and structural constraints to estimate that linkage took place between $0.6 \mathrm{Ma}$ and $1 \mathrm{Ma}$. Calculated pre- and post-linkage throw rates are 0.6 and $2 \mathrm{~mm} / \mathrm{yr}$ respectively. Maximum knickpoint retreat rates upstream of the faults range from 4.5 to $28 \mathrm{~mm} / \mathrm{yr}$, faster than for similar catchments upstream of normal faults in the Central Apennines and the Hatay Graben of Turkey, and implying a fluvial landscape response time of 1.6 to $2.7 \mathrm{Myr}$. We explore the relative controls of drainage area and precipitation on these retreat rates, and conclude that while climate variation and fault throw rate partially explain the variations seen, 


\section{Introduction}

Fluvial geomorphology can give qualitative and quantitative insights into tectonics. In steady state landscapes, channel steepness indices and chi analyses have been directly linked to rock uplift rates (Snyder et al., 2000; Whipple, 2001; Kirby et al., 2003; Ouimet et al., 2009; Mudd et al., 2014), although the form of this relationship varies across a range of settings (Kirby and Whipple, 2012; Whittaker, 2012). In transient landscapes responding to a tectonic perturbation, studies have addressed the way in which the fluvial system records changes in tectonic uplift rate in time and space, particularly with respect to the formation, generation and upstream advection of knickpoints (Whipple and Tucker, 2002; Wobus et al., 2006b; Whittaker et al., 2008; Whittaker and Boulton, 2012; Kirby and Whipple, 2012; Royden and Perron, 2013). In bedrock fluvial systems, a knickpoint (here defined as the point where the rate of change of the channel gradient reaches a local maximum) can be initiated following a change in boundary conditions, such as an increase in fault slip rate (Snyder et al., 2000; Whipple and Tucker, 2002; Crosby and Whipple, 2006; Whittaker et al., 2008; Whittaker and Boulton, 2012). The increase in channel steepness, caused by faster throw rates, drives locally enhanced river incision. Consequently, the knickpoint migrates upstream, and the effects of the new tectonic boundary conditions are propagated throughout the catchment (Crosby and Whipple, 2006; Gasparini et al., 2006; Whittaker et al., 2008).

Analysis of transient river long profiles and knickpoint retreat offers an analytically tractable way of extracting tectonic information from the landscape (Royden and Perron, 2013; Mudd et al., 2014). Studies that tackle this problem are increasingly varied and include field and remote sensing approaches (Bishop et al., 2005; Whittaker et al., 2007a; Boulton and Whittaker, 2009; Miller et al., 2012; Boulton et al., 2014), formal numerical inversion methods (Roberts and White, 2010; Goren et al., 2014; Rudge et al., 2015) and comparative landscape evolution modelling (Cowie et al., 2006; Attal et al., 2008; Gasparini and Whipple, 2014). These studies potentially allow tectonic rates and fault throw rates to be determined, even when geodetic, geologic or other geomorphic constraints are sparse, and consequently, they have conceivably important implications for seismic hazard (Kirby et al., 2008; Boulton and Whittaker, 2009).

This paper addresses this challenge to derive new constraints on fault slip rates and landscape response times in the Gediz Graben (Western Turkey). We investigate the evolution of the southern margin of the graben from the late Pliocene to recent and explore the interaction between active faulting and the fluvial system. In particular, we: (i) evaluate the differences in the longitudinal profiles of the rivers crossing the active high-angle graben-bounding normal faults; (ii) identify knickpoints initiated by tectonic processes, and identify landscape transience; (iii) relate these to fault throw and estimate fault slip rate; and (iv) determine the effects of differing boundary conditions (e.g. tectonics, climate, mapped lithology) on knickpoint retreat rates and hence landscape response times.

\section{Existing work}

Upstream propagation of knickpoints in response to boundary condition change can be seen in terms of both horizontal and vertical vectors (Wobus et al., 2006a; Whittaker and Boulton, 2012). The progress of knickpoints upstream in plan view is influenced by several factors including drainage area and lithology (Whipple, 2004; Wobus et al., 2006a, 2006b; Whittaker et al., 2007a, 2008; Attal et al., 2008). The form of any stream power law is a non-linear kinematic wave with an intrinsic wave celerity that can be used to represent the planform knickpoint retreat rate (Tucker and Whipple, 2002; Whipple and Tucker, 
5/18/2017 Normal fault growth and linkage in the Gediz (Alaşehir) Graben, Western Turkey, revealed by transient river long-profiles and slope-break knickpoin...

2002; Wobus et al., 2006a, 2006b; Whittaker et al., 2008; Whittaker and Boulton, 2012). The celerity ( $\left.C_{E}\right)$ can be represented as

$C_{E}=\psi A^{m} S^{n-1}$

where $A$ is the upstream area, $S$ is the channel gradient and $m$ and $n$ are positive exponents. $\psi$ is a parameter that represents all of the other controls on the knickpoint retreat velocity, including sediment flux and width effects (Whittaker et al., 2007b; Attal et al., 2011). When the erosion rate is dependent upon the rate of energy expenditure per unit width (unit stream power), and hydraulic width scaling is subsumed into the exponent on $A$ (i.e. $m=0.5$ and $n=1$ ), $C_{E}$ should solely be a function of $A^{0.5}$ (Tucker and Whipple, 2002; Attal et al., 2008). Consequently $\psi$ can be thought of as a drainage-area normalised knickpoint retreat parameter (Whittaker et al., 2008) and rivers with greater drainage areas (and hence discharges) have knickpoints that retreat faster in a predictable manner (Tucker and Whipple, 2002; Berlin and Anderson, 2007; Attal et al., 2008). This upstream retreat rate fundamentally controls landscape response times to a tectonic perturbation (Attal et al., 2008).

A number of field studies confirm that drainage area, and not slope, predominantly controls knickpoint retreat rate (Wobus et al., 2006b; Berlin and Anderson, 2007; Crosby et al., 2007; Whittaker et al., $2007 \mathrm{~b}$ ) and that knickpoints may take $>10^{6}$ years to propagate through catchments (Whittaker and Boulton, 2012). In principle, lithology influences knickpoint retreat rate because it should affect bedrock erodibility, which is implicitly imbedded in the parameter $\psi$ in Equation (1) (Goldrick and Bishop, 2007; Anthony and Granger, 2007; Cook et al., 2009; Schildgen et al., 2012; Whitbread et al., 2015). However, converting measures of rock strength, fracture density or weathering into a measure of bedrock erodibility remains a challenging problem (cf. Bursztyn et al., 2015), while a number of knickpoint studies (Stock and Montgomery, 1999; Whittaker and Boulton, 2012) have concluded that lithology seemingly has little relative influence on documented retreat rates. Climate also plays a significant role in controlling landscape response times, through the amount and variability of run off and through the growth or absence of vegetation (Ferrier et al., 2013).

In contrast to the plan view celerity discussed above, the vertical rate of knickpoint propagation upstream in a catchment is theoretically independent of drainage area. Instead it is fundamentally dependent on the relative magnitude of tectonic perturbation or base-level fall generating the knickpoint (Wobus et al ., 2006b; Crosby et al., 2007; Whittaker and Boulton, 2012). Consequently, knickpoints propagate upwards through the landscape predictably, and at greater speed if the tectonic perturbation is larger (Boulton and Whittaker, 2009; Whittaker and Walker, 2015). For cases in which knickpoints are measured according to their vertical height above an active fault, the height should scale with the throw rate on the structure since formation, or since it started to move at its current rate (Attal et al., 2008). For normal faults, it is important to stress that although the ratio of footwall uplift to hanging wall subsidence can vary in different settings (Anders et al., 1993; Densmore et al., 2007; Whittaker and Walker, 2015), explicit constraints on the partitioning of the displacement between these two components are not needed for the above analysis. This is because rivers respond to the total throw rate difference across the fault, minus any sediment aggradation in the (typically under-filled) hanging wall which would counteract the relative base level fall (Whittaker et al., 2007b). A number of field studies have now linked the heights of the knickpoints upstream to the rate of fault movement and have clearly verified these general principles (Harkins et al., 2007; Boulton and Whittaker, 2009; Whittaker, 2012), including for active normal faults in Greece (Whittaker and Walker, 2015), the Italian Apennines and Turkey (Whittaker and Boulton, 2012), which have undergone fault interaction and linkage.

The time span over which rivers respond to base-level changes, and thus the timescale taken to pass effects to the surrounding landscape is fundamentally determined by knickpoint migration rates (Whipple and Tucker, 1999; Whipple et al., 2000; Whipple, 2004; Wobus et al., 2006a). A number of studies have suggested that this process can take several million years (Merritts and Bull, 1989; Snyder et al., 2000; Whipple, 2001; Whittaker and Boulton, 2012; Stephenson et al., 2014). Consequently, this makes rivers 
5/18/2017 Normal fault growth and linkage in the Gediz (Alaşehir) Graben, Western Turkey, revealed by transient river long-profiles and slope-break knickpoin... ideal natural laboratories for evaluation of the landscape response to active faulting over Pliocene to Recent timescales.

\section{Geological Background}

The Gediz (or Alaşehir) Graben lies (Figure 1) within the Western Anatolian Extensional Province (WAEP), an area of active extensional tectonics (Dewey and Şengör, 1979; Bozkurt and Mittwede, 2005; ten Veen et al., 2009; Çiftçi and Bozkurt, 2009b, 2010; Kent et al., 2016). The formation of the Gediz Graben occurred as a two-stage process, which was initiated at 16 Ma with uplift and subsidence occurring primarily along a laterally continuous low-angle detachment fault (Koçyiğit et al ., 1999; Seyitoğlu et al., 2002; Bozkurt and Sözbilir, 2004; Purvis and Robertson, 2004; Buscher et al., 2013). At 2.6-2 Ma the dominant style of faulting switched to high-angle normal faulting along the southern graben margin (Buscher et al., 2013). 


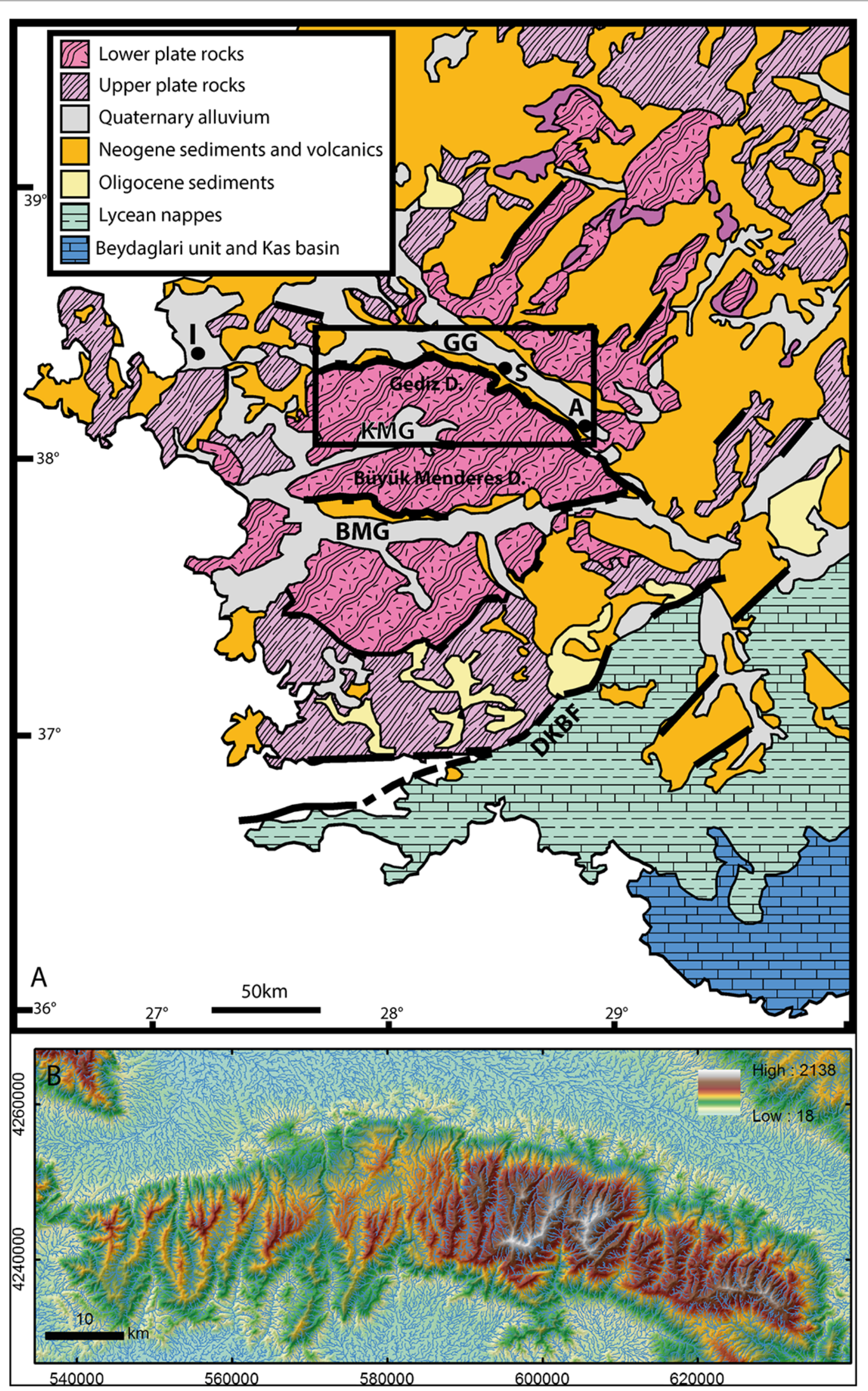




\section{Figure 1.}

\section{Open in figure viewer}

(A) Simplified geological map of the Western Anatolian Extensional Province (adapted from Bozkurt, 2000, 2003; Seyitoğlu et al., 2004; Çemen et al., 2006; Kent et al., 2016); the box shows the location of Figures 2 and 4. GG, Gediz Graben; KMG, Küçük Menderes Graben; BMG, Büyük Menderes Graben; DKBF, Datça-Kale Breakaway Fault (Seyitoğlu et al ., 2004), also known as the South West Anatolian Shear Zone (Çemen et al., 2006). Key towns: A, Alaşehir; S, Sahlili; I, Izmir. (B) ASTER digital elevation model (NASA Land Processes Distributed Active Archive Center, 2001) of the Bozdağ Mountains and Gediz Graben showing the DEM derived river network (extent shown in Figure $1(\mathrm{~A})$ ).

The modern topographic graben is $120 \mathrm{~km}$ long with a roughly E-W oriented graben axis (Figures 1, 2). Along the southern margin the high-angle normal faulting occurs on three segments that form the $120 \mathrm{~km}$ long Gediz Graben fault array. The longest fault segment is the central Salihli segment, $47 \mathrm{~km}$ in length, while the eastern Alaşehir segment is $42 \mathrm{~km}$ long and the western Turgutlu segment is $35 \mathrm{~km}$ in length (Figure 2(a)). Uplift along the southern margin has formed the highly incised, $\sim 2 \mathrm{~km}$ high Bozdağ Range, which is dominated by the metamorphic central Menderes sub-massif. Regional mapping shows the massif is predominantly composed of gneisses and sub-ordinate schists and Cenozoic granites (Sengör et al., 1984; Bozkurt, 2003; Seyitoğlu et al., 2004; Çemen et al., 2006) (Figure 2). Younger Mio-Pliocene sedimentary units are uplifted in the proximal footwalls of the fault segments (green units, Figure 2), including sandstones and conglomerates derived from the metamorphic basement (Purvis and Robertson, 2005; Çiftçi and Bozkurt, 2009b). Time-averaged throw rates have been calculated from geological data and footwall relief measurements for the high-angle normal faults bounding the present day topographic graben, assuming these normal faults have been active from $\sim 2.6 \mathrm{Ma}$ to the present day (Kent et al., 2016). The average throw rate calculated over the Turgutlu, Salihli and Alaşehir fault segments are 0.7 $\mathrm{mm} / \mathrm{yr}, 1.2 \mathrm{~mm} / \mathrm{yr}$ and $1.0 \mathrm{~mm} / \mathrm{yr}$, respectively, for the last 2.6 My (Kent et al., 2016). The highest values of throw rates are found towards the centre of the fault array, $1.2 \mathrm{~mm} / \mathrm{yr}$ at $72 \mathrm{~km}$ along strike, and the lowest values $\sim 0.5 \mathrm{~mm} / \mathrm{yr}$ are at the ends of the fault array. These values increase to $1.5 \mathrm{~mm} / \mathrm{yr}$ and 0.6 $\mathrm{mm} / \mathrm{yr}$ if $2 \mathrm{Ma}$ is taken as the time of fault initiation. Where the mapped extent of the eastern and western segments meet the central fault segment, there are non-zero values for the fault throw, which suggests that at least one fault linkage event has occurred between the fault segments since fault initiation. Consequently these time-averaged rates may disguise a temporal acceleration in throw rate due to this process (Cowie and Roberts, 2001; Hopkins and Dawers, 2015). 


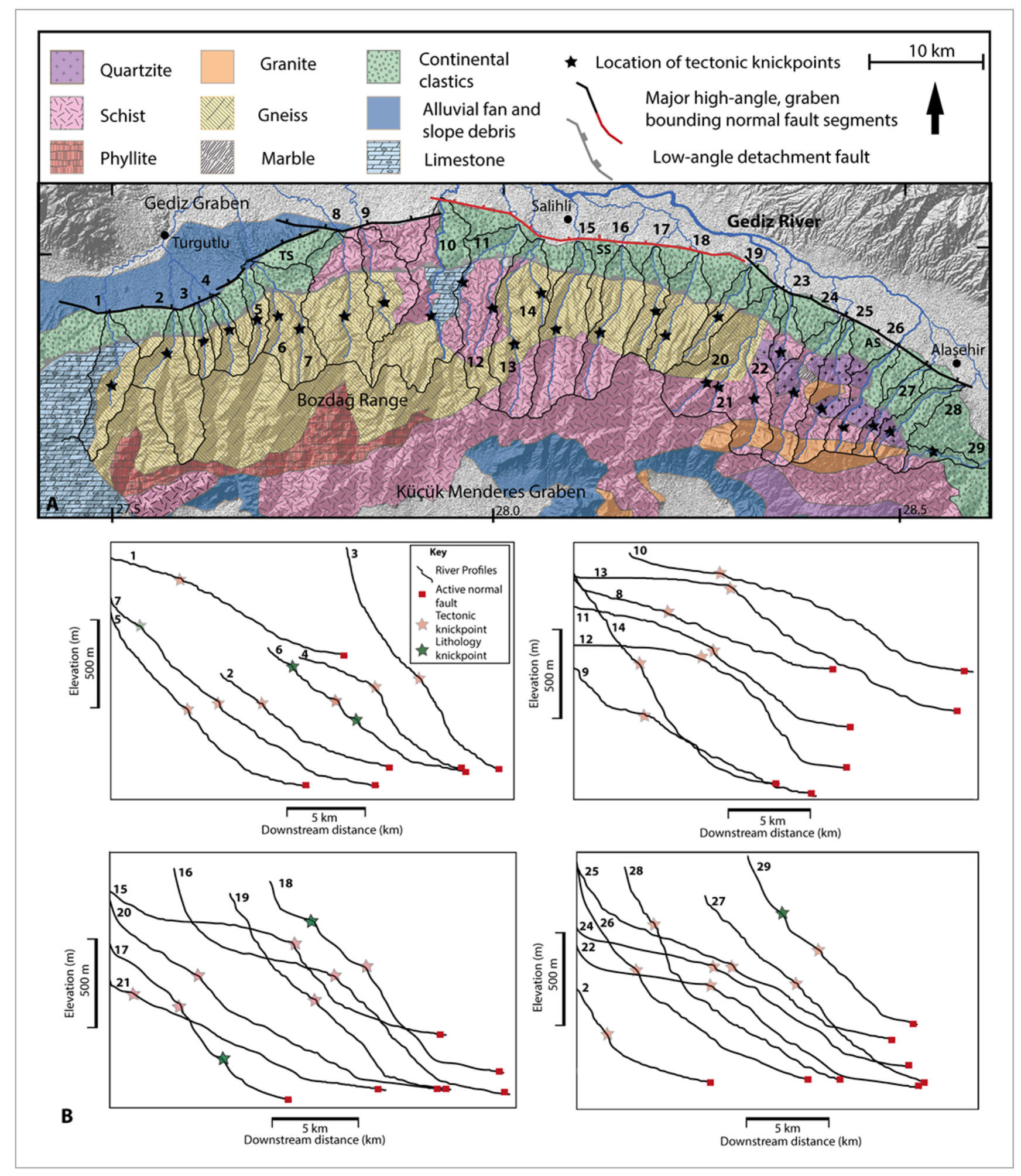

Figure 2.

Open in figure viewer

(A) A simplified geological map showing the main lithologies in the Gediz Graben and the significant regional faults (same extent as Figure 1(B)), a low angle detachment and an array of high-angle normal faults that bound the modern topographic graben (modified from Bozkurt, 2003; Seyitoğlu et al., 2004; Çemen et al., 2006; Kent et al., 2016). Note that the easternmost Alaşehir segment (AS) ruptured in the 1969 earthquake. Overlain are the rivers, catchments and tectonic knickpoints extracted for this study. SS - Salihli segment; TS - Turgutlu segment. (B) Long profiles for the 29 rivers extracted that drain the Bozdağ Range and cross the 
5/18/2017 Normal fault growth and linkage in the Gediz (Alaşehir) Graben, Western Turkey, revealed by transient river long-profiles and slope-break knickpoin...

active high-angle normal fault array. The catchment locations for each of the rivers are shown in part A. The location where the river intersects the active normal fault is shown with a red dash and the position of the tectonic knickpoint for each river is marked with a star.

GPS data show that extension is still occurring in the WAEP indicating $10 \pm 5 \mathrm{~mm} / \mathrm{yr}$ of extension distributed between the Gediz and Büyük Menderes grabens yielding an opening rate of $6 \mathrm{~mm} / \mathrm{yr}$ and $4 \mathrm{~mm} / \mathrm{yr}$ for the Büyük Menderes and Gediz Graben, respectively (Barka and Reilinger, 1997; Aktug et al., 2009).

Furthermore, the extensional tectonic regime of western Turkey has led to significant historic earthquakes in the region (Guidoboni et al., 1994; Guidoboni and Comastri, 2005). Of note within the Gediz Graben was the 1969 Alaşehir earthquake of magnitude $\sim 6.9$, which formed a surface rupture $\sim 30 \mathrm{~km}$ in length on the Alaşehir segment (Arpat and Bingöl, 1969; Eyidoğan and Jackson, 1985). Therefore, a detailed understanding of the pattern and rates of fault motion is necessary for robust assessments of current seismic hazard in the region.

\section{Methods}

Topographic data for the Gediz Graben were acquired from the Advanced Spaceborne Thermal Emission and Reflection Radiometer (ASTER) digital elevation model (DEM) data, with $30 \mathrm{~m}$ resolution (NASA https://wist.echo.nasa.gov/api/). The drainage network for the graben was extracted using standard Arc hydrology tools (Figure 1(b)). A threshold value of 300 pixels was used to create a stream network, giving a stream-forming drainage area threshold $0.27 \mathrm{~km}^{2}$, which we confirmed against 'blue-lined' streams on conventional topographic maps. 24 major catchments containing one or more rivers that flow across the southern graben-bounding fault were identified (Figure 2(a)) and 29 rivers for study were selected that originate at or near the drainage divide. Using the RiverTools software, the long profile of each river (Figure 3(b)), the channel slope, $S$, and drainage area, $A$, as a function of downstream distance, L, was derived. Reach-average channel gradients were calculated using elevation differences of $15 \mathrm{~m}$. Linear regression was undertaken on log-log slope-drainage area plots for each river in order to calculate normalised channel steepness index, $\mathrm{k}_{\mathrm{sn}}$ where,

$\mathrm{S}=\mathrm{k}_{\mathrm{sn}} \mathrm{A}^{- \text {- } \text { ref }}$

and $\theta$ is the channel concavity. A standard concavity of 0.45 was used to derive the normalised steepness index (cf. Wobus et al ., 2006a) to enable comparison between different rivers in the graben that vary in terms of their absolute concavity. Where knickpoints were present in the long profile, normalised steepness indices were derived for (i) upstream of the fault and downstream of the knickpoints and (ii) upstream of the knickpoint and downstream of the drainage divide. 


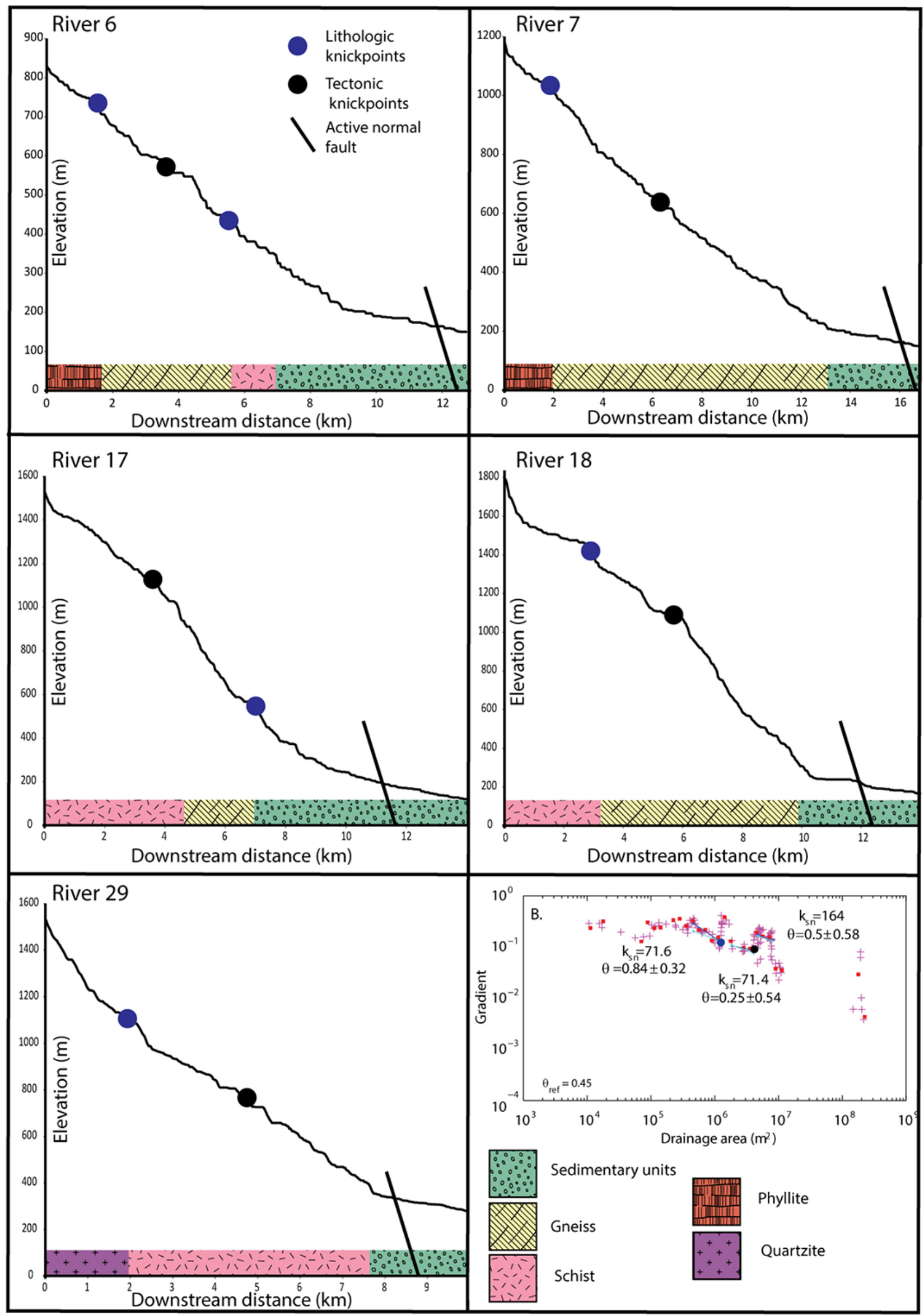

Figure 3.

Open in figure viewer 
5/18/2017 Normal fault growth and linkage in the Gediz (Alaşehir) Graben, Western Turkey, revealed by transient river long-profiles and slope-break knickpoin...

The long profiles of four rivers that contain lithological knickpoints. The lithologies that the channel incises through are displayed under the profile, and both the lithologic and tectonic knickpoints are shown. (B) Inset slope-area graph of river 29 showing vertical step knickpoint associated with the lithological knickpoint (blue) and the slope break knickpoint associated with the tectonically induced knickpoint (black).

A knickzone can be defined as a large-scale convexity in a river longitudinal profile, and a knickpoint as the precise profile break where the rate of change of the channel gradient is greatest in the river profile (Kirby et al., 2003; Crosby and Whipple, 2006; Wobus et al., 2006a; Pederson and Tressler, 2012; Whittaker and Boulton, 2012). The knickzones and knickpoints identified here are large in scale (hundreds to thousands of metres), thus influence a significant portion of each catchment by length. It is stressed that this study is not concerned with small-scale or localised waterfall-type gradient changes, which are sometimes called knickpoints (cf. Bishop et al., 2005; Whittaker et al., 2007a). Robust knickpoint locations were derived by plotting the reach-averaged slope data against downstream distance for each profile with the river profile overlaid. Having constrained knickpoint locations in each river, the vertical height of the knickpoint above the active fault, the upstream drainage and the downstream distance to the knickpoint, and the along-strike position, relative to the graben margin (Table 1) were extracted from the DEM. Errors in estimating knickzone heights reflect uncertainties in the elevation of the basin-bounding fault and the exact location of the knickpoint on the long profile. An empirically-derived error of $\pm 10 \%$ reflects this uncertainty.

Table 1. Data extracted for the 29 rivers considered in this study. The knickpoint data in this table are for the tectonically induced knickpoints identified in each river and the active normal fault that they cross.

\begin{tabular}{|c|c|c|c|c|c|c|c|}
\hline River & $\begin{array}{c}\text { Distance } \\
\text { along } \\
\text { strike } \\
(\mathrm{km})\end{array}$ & $\begin{array}{c}\text { Drainage } \\
\text { area } \\
\left(\mathbf{k m}^{2}\right)\end{array}$ & $\begin{array}{l}\text { River } \\
\text { length to } \\
\text { fault } \\
\text { (km) }\end{array}$ & $\begin{array}{c}\text { Drainage } \\
\text { area at } \\
\text { knickpoint } \\
\left(\mathbf{k m}^{2}\right)\end{array}$ & $\begin{array}{l}\text { Knick- } \\
\text { point } \\
\text { elevation } \\
\text { (m) }\end{array}$ & $\begin{array}{l}\text { Knickpoint } \\
\text { distance } \\
\text { downstream } \\
(\mathbf{k m})\end{array}$ & $\begin{array}{l}\text { Knick-point } \\
\text { distance from } \\
\text { fault (km) }\end{array}$ \\
\hline 1 & 5.6 & 49.1 & 14.7 & 20.8 & 525 & 5.4 & 9.4 \\
\hline 2 & 12.8 & 63.9 & 10.8 & 6.0 & 519 & 2.7 & 8.1 \\
\hline 3 & 15.3 & 9.6 & 9.2 & 5.9 & 670 & 4.9 & 4.3 \\
\hline 4 & 17.7 & 18.3 & 10.3 & 11.5 & 619 & 4.8 & 5.5 \\
\hline 5 & 22.7 & 18.5 & 12.5 & 5.3 & 598 & 4.9 & 7.6 \\
\hline 6 & 22.7 & 63.0 & 12.0 & 16.2 & 550 & 4.5 & 7.5 \\
\hline 7 & 22.7 & 90.0 & 16.8 & 14.2 & 612 & 6.6 & 10.2 \\
\hline 8 & 32.9 & 79.5 & 16.4 & 20.6 & 520 & 5.6 & 10.8 \\
\hline 9 & 35.4 & 46.7 & 15.1 & 11.6 & 645 & 4.8 & 10.4 \\
\hline 10 & 44.6 & 105.2 & 22.2 & 19.2 & 785 & 5.6 & 16.6 \\
\hline 11 & 53.4 & 73.2 & 18.2 & 12.6 & 681 & 8.5 & 9.7 \\
\hline 12 & 53.4 & 73.5 & 17.2 & 27.2 & 780 & 9.8 & 7.4 \\
\hline
\end{tabular}


5/18/2017 Normal fault growth and linkage in the Gediz (Alaşehir) Graben, Western Turkey, revealed by transient river long-profiles and slope-break knickpoin...

\begin{tabular}{|c|c|c|c|c|c|c|c|}
\hline River & $\begin{array}{c}\text { Distance } \\
\text { along } \\
\text { strike } \\
(\mathbf{k m})\end{array}$ & $\begin{array}{c}\text { Drainage } \\
\text { area } \\
(\mathbf{k m})\end{array}$ & $\begin{array}{l}\text { River } \\
\text { length to } \\
\text { fault } \\
(\mathbf{k m})\end{array}$ & $\begin{array}{c}\text { Drainage } \\
\text { area at } \\
\text { knickpoint } \\
(\mathrm{km})\end{array}$ & $\begin{array}{l}\text { Knick- } \\
\text { point } \\
\text { elevation } \\
(\mathrm{m})\end{array}$ & $\begin{array}{c}\text { Knickpoint } \\
\text { distance } \\
\text { downstream } \\
(\mathbf{k m})\end{array}$ & $\begin{array}{l}\text { Knick-point } \\
\text { distance from } \\
\text { fault (km) }\end{array}$ \\
\hline 13 & 56.3 & 82.7 & 24.1 & 29.4 & 1002 & 9.4 & 14.7 \\
\hline 14 & 56.3 & 82.7 & 12.8 & 4.2 & 950 & 4.1 & 8.7 \\
\hline 15 & 60.3 & 71.1 & 21.0 & 37.1 & 945 & 10.7 & 10.3 \\
\hline 16 & 65.4 & 59.8 & 20.2 & 26.9 & 1156 & 9.8 & 10.4 \\
\hline 17 & 69 & 27.0 & 11.9 & 9.8 & 1124 & 4.3 & 7.6 \\
\hline 18 & 73.7 & 47.8 & 14.6 & 7.9 & 1040 & 5.6 & 9.0 \\
\hline 19 & 79.2 & 22.0 & 13.7 & 8.5 & 837 & 6.1 & 7.7 \\
\hline 20 & 79.8 & 118.6 & 20.8 & 7.0 & 1131 & 5.5 & 15.2 \\
\hline 21 & 79.8 & 118.6 & 17.2 & 16.5 & 710 & 5.9 & 11.3 \\
\hline 22 & 82.8 & 119.2 & 21.4 & 24.6 & 930 & 8.6 & 12.8 \\
\hline 23 & 85 & 15.0 & 8.4 & 2.1 & 602 & 1.7 & 6.7 \\
\hline 24 & 90 & 53.4 & 20.5 & 20.4 & 920 & 8.7 & 11.9 \\
\hline 25 & 91.5 & 42.7 & 19.0 & 16.0 & 870 & 7.0 & 12.0 \\
\hline 26 & 97.2 & 34.3 & 14.5 & 3.8 & 1000 & 3.7 & 10.8 \\
\hline 27 & 100.9 & 22.3 & 13.2 & 8.1 & 954 & 4.5 & 8.7 \\
\hline 28 & 105.1 & 29.1 & 13.6 & 6.4 & 1010 & 5.8 & 7.8 \\
\hline 29 & 110 & 7.7 & 7.8 & 5.9 & 781 & 5.1 & 2.7 \\
\hline
\end{tabular}

Lithology can cause knickpoints to form through differences in erodibility (Snyder et al., 2000; Baldwin et al., 2003; Duvall et al., 2004; Anthony and Granger, 2007; Goldrick and Bishop, 2007; Whittaker et al., 2007a). Consequently, it was necessary to identify any lithological-instigated knickpoints so that these could be excluded from the analysis of knickpoints related to fault movement. Knickpoints initiated by lithology were identified (i) by determining where the rivers cross boundaries between different lithologies using geologic maps and field observations (Purvis and Robertson, 2004, 2005; Çiftçi and Bozkurt, 2009a; Oner and Dilek, 2011) and (ii) through the use of a log-log plot of drainage area against slope where 'vertical-step' knickpoints (Goldrick and Bishop, 2007), which do not have a change in steepness index across the knickpoint, were recognised (Haviv et al., 2010; Pederson and Tressler, 2012). These knickpoints clearly contrast with those driven by a relative base-level fall, in which steepness index is measurably higher downstream of knickpoint. Any verified lithological knickpoints (examples, Figure 3) were excluded from further consideration in this study. Typically these were found to be either pinned to the contact between the sedimentary units and the metamorphic basement, or at the boundary between different metamorphic lithologies. The reasonable assumption was made that the knickpoint (the top of the convex reach) upstream of the active normal faults in each long profile is the distance upstream that the 
5/18/2017 Normal fault growth and linkage in the Gediz (Alaşehir) Graben, Western Turkey, revealed by transient river long-profiles and slope-break knickpoin...

wave-like response to tectonic perturbation has travelled (Crosby and Whipple, 2006; Whittaker et al., 2007b, 2008; Berlin and Anderson, 2007; Attal et al., 2011); this distance upstream of the fault was measured using the along stream distance on the DEM.

\section{Results}

All the extracted rivers drain in a broadly northern direction into the Gediz River, which runs along the axis of the Gediz Graben. The length of the rivers varies between $7.8 \mathrm{~km}$ and $24.1 \mathrm{~km}$, with the longest rivers in the centre of the range, and shorter rivers at the range margins. There is a corresponding variation in the size of the catchment area for each river from $7.7 \mathrm{~km}^{2}$ to $119.1 \mathrm{~km}^{2}$ (Table 1). The catchments are elongate with their long axis parallel to the regional extension in a NNE-SSW direction (Figure 2(a)).

The Bozdağ Range displays a marked topographic asymmetry with the shallow dipping Gediz Detachment to the north creating a wide, gently sloping range to the drainage divide. Steep topography forms the southern part of the range bounding the adjacent Küçük Menderes Graben. The drainage divide through most of the mountain range is situated close to the Küçük Menderes Graben, although it is more central in the eastern part of the mountains.

Significantly, all rivers draining the Bozdağ Range and crossing the margin-bounding fault of the graben have convex long profiles. Associated knickpoints, defined using the methodologies discussed above, are identified in each of the rivers studied (Figure 3; Table 1). All rivers contain at least one non-lithologic knickpoint, identified from slope-area analysis, upstream of the active fault. The plan-view distance upstream that the tectonic knickpoint in each river has migrated varies along strike of the mountain range (Figure 2(a)). However, when the distance of each knickpoint upstream of the fault is plotted against the drainage area, A, of each river catchment (Figure 4), it is evident that the knickpoints within the channels with the largest catchments have travelled further upstream. For example, river 10 has a catchment drainage area of $105.2 \mathrm{~km}^{2}$ and the knickpoint has travelled $16.6 \mathrm{~km}$ upstream, while river 4 , which has a drainage area of $18.3 \mathrm{~km}^{2}$, has a knickpoint that has travelled only $5.5 \mathrm{~km}$ upstream. 


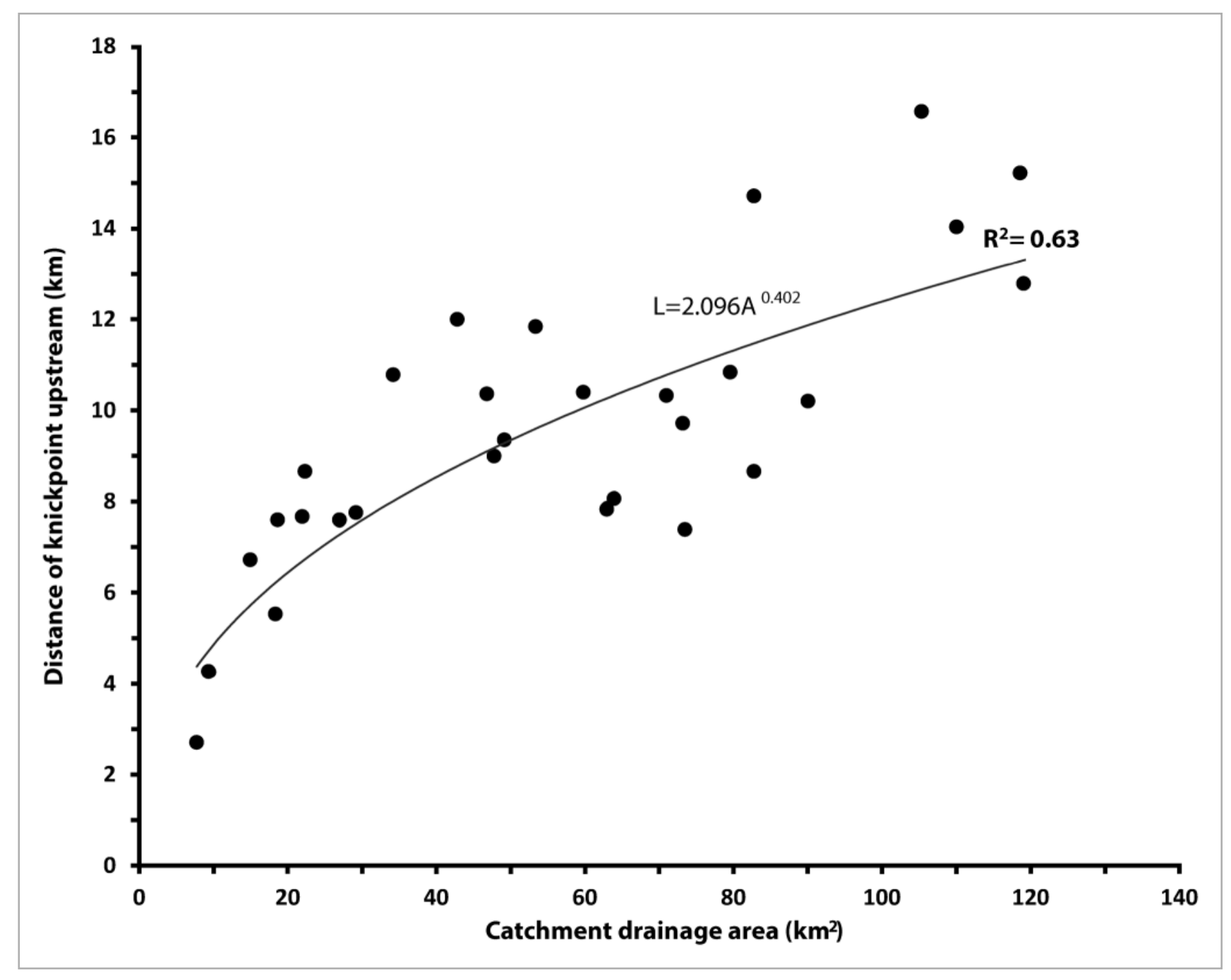

\section{Figure 4.}

\section{Open in figure viewer}

Graph showing the distance of the knickpoint upstream plotted against drainage area of the river catchment. The data show a trend towards greater distances retreated by the knickpoint with increasing catchment area of the river.

The vertical heights of knickpoints, measured relative to the basin bounding fault in each catchment, varies systematically along the strike of the graben (Figure 5). The highest knickpoint is $1029 \mathrm{~m}$ above the fault occurring in river 16 , at $65.4 \mathrm{~km}$ along strike of the range front, and approximately half-way along the fault segment. The lowest knickpoints are found at the western end of the range, at $346 \mathrm{~m}$ to $550 \mathrm{~m}$ above the fault. At the eastern end of the range the knickpoint elevations are higher, ranging from $427 \mathrm{~m}$ to $800 \mathrm{~m}$ above the fault (Figure 5; Table 1). 


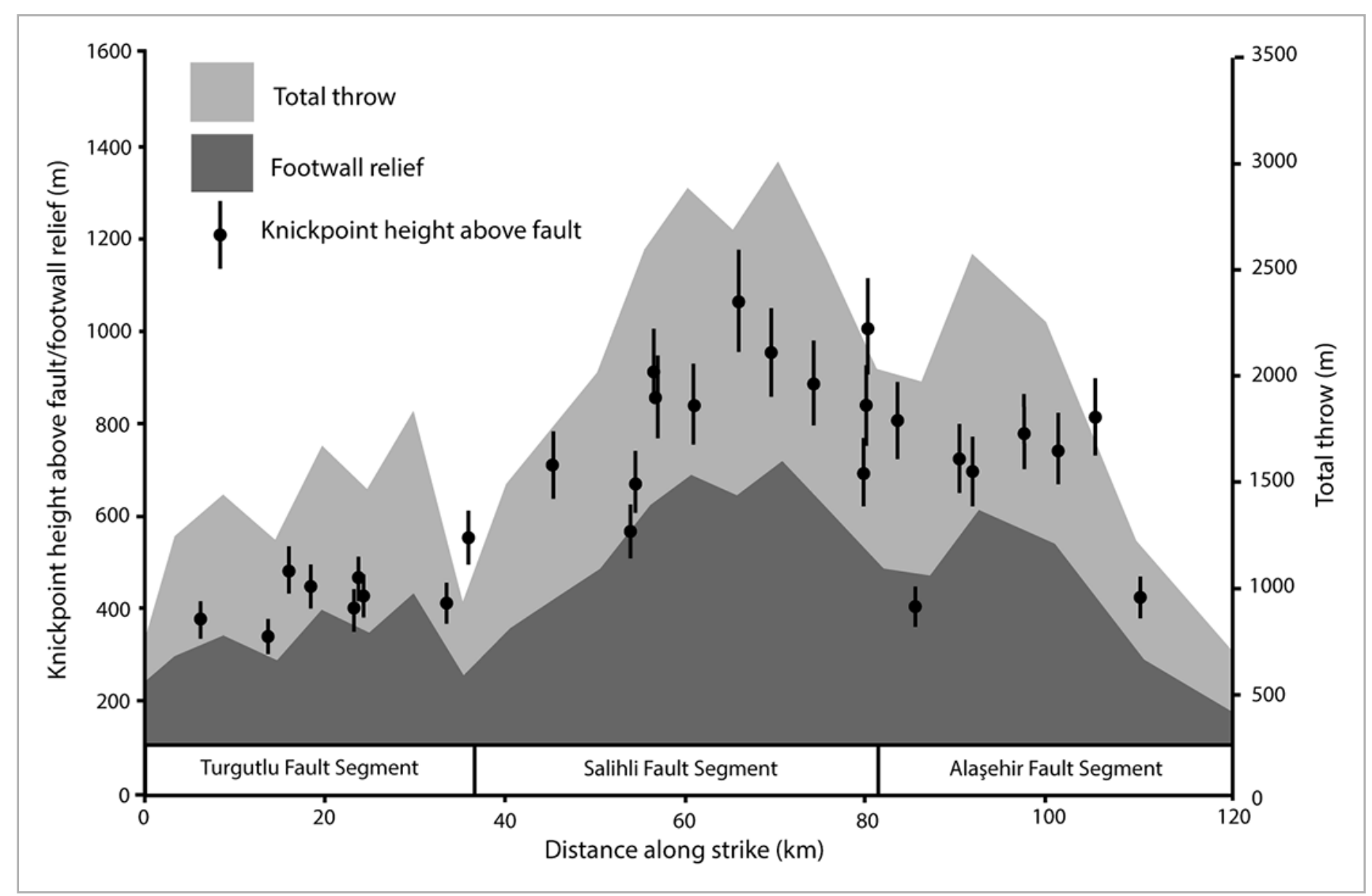

Figure 5.

Open in figure viewer

The heights of the knickpoints above the active fault plotted along strike, with the total throw and footwall relief superimposed. An error of $10 \%$ has been assigned to the knickpoint data to account of the variations in knickpoint placement between methods. The data shows that the heights of the knickpoints mirror the trends in the total throw and footwall relief.

The height of the knickpoints above the fault correlates well with the relative values of footwall relief and total throw on the active high-angle normal faults bounding the graben, which were first presented in Kent et al. (2016). In that study, Kent et al ., compared fault throw measurements, derived from structural and seismic analysis, with the topographic relief in the Gediz Graben between the valley floor and the top of the exhumed basin sediments along the southern margin. This approach was used as the total relief also contains information on the earlier uplift of the margin along the low-angle detachment fault in addition to the younger uplift resulting from high-angle faulting. The total throw increases towards the centre of the fault array (Figure 5). Similarly, the height of the knickpoint above the active fault in the centre of the range increases by a factor of 3 compared with the fault tips. Moreover, the three fault segments are clearly expressed in the footwall relief profile along strike of the fault, and are marked by throw minima at $38 \mathrm{~km}$ and $85 \mathrm{~km}$ along strike. Rivers located at the fault segment boundaries have knickpoints with vertical heights of several hundred metres.

To test the relationship between knickpoint height and the magnitude of the normal fault throw, knickpoint heights above the fault are plotted against the high-angle normal fault footwall relief and the inferred total throw documented in Kent et al. (2016) (Figure 6). These data show that knickpoint height can be related to both relief and total throw with a linear relationship $\left(r^{2}=0.52\right)$. The equation of the line of best fit for the plot of knickpoint height versus footwall relief has a gradient of $\sim 1$, and therefore knickpoints heights are generally similar in magnitude to the footwall relief (Figure 6(a)). However, knickpoint heights are only a small fraction of the total geological throw (35\% on average). Figure $6(\mathrm{~b})$ illustrates how the knickpoints 
5/18/2017 Normal fault growth and linkage in the Gediz (Alaşehir) Graben, Western Turkey, revealed by transient river long-profiles and slope-break knickpoin... record both footwall uplift and total throw variations with a reasonable degree of fidelity, suggesting that they are recording variations in fault displacement along the strike of the basin-bounding structure.

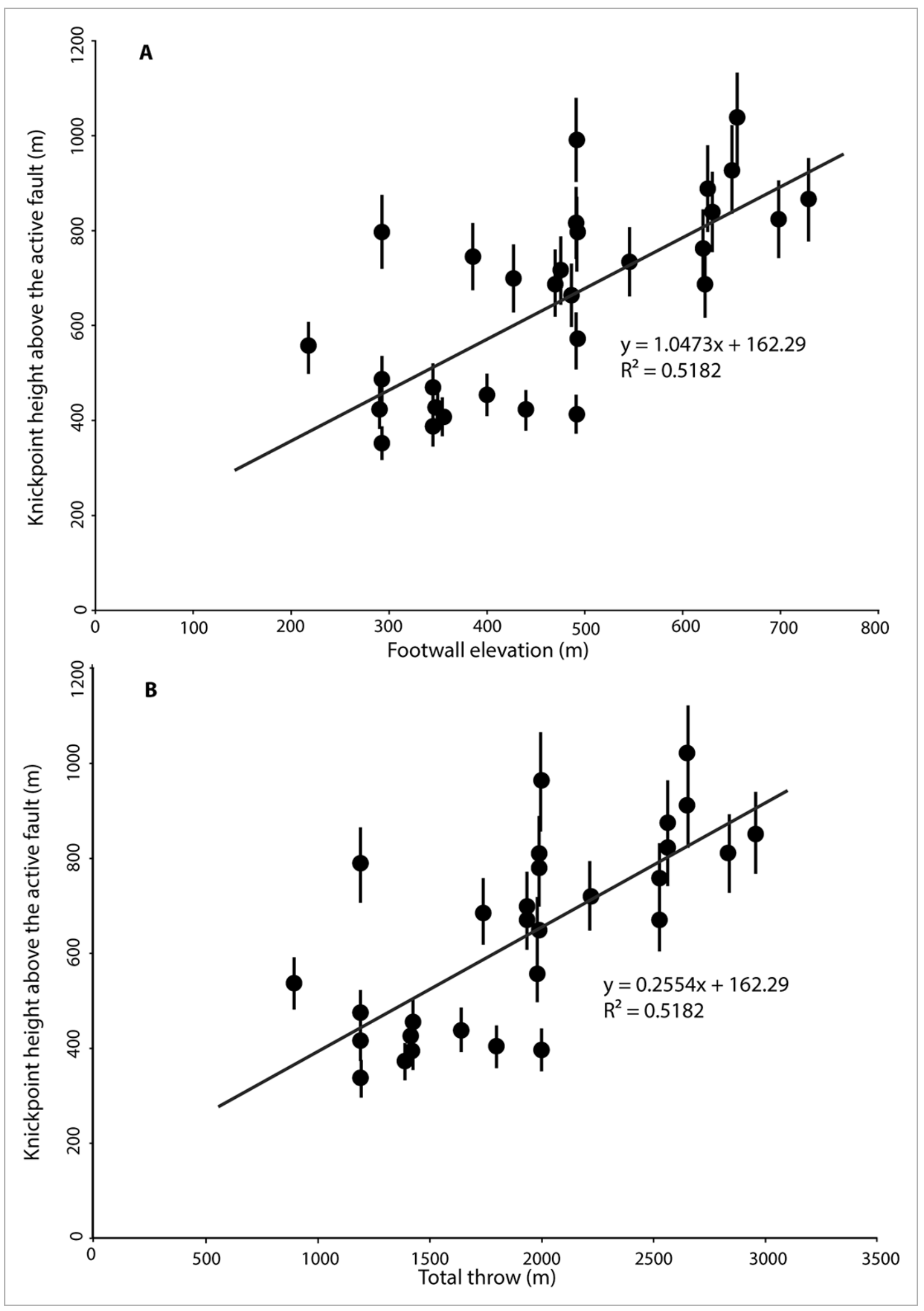

Figure 6. 
5/18/2017 Normal fault growth and linkage in the Gediz (Alaşehir) Graben, Western Turkey, revealed by transient river long-profiles and slope-break knickpoin...

Open in figure viewer

Plots of knickpoint height above the fault against (A) the extracted relief of the footwall and (B) the calculated total throw on the active normal faults. The red lines represent a linear regression.

There is a trend towards greater height of the knickpoint above the fault with higher topography.

Channel steepness indices $\left(\mathrm{k}_{\mathrm{sn}}\right)$ for each study river were also derived for channel reaches upstream and downstream of each knickpoint (Figure 7(a)); these show significant variations between each data set. Upstream of the knickpoints, the $\mathrm{k}_{\mathrm{sn}}$ values for each river range between $17.8 \mathrm{~m}^{0.9}$ and $95.3 \mathrm{~m}^{0.9}$ (grey points, Figure $7(\mathrm{a})$ ). There is also little systematic variation in $\mathrm{k}_{\mathrm{sn}}$ along the strike of the fault array. In contrast, the values of $\mathrm{k}_{\mathrm{sn}}$ downstream of the knickpoints, but upstream of the faults, are consistently higher than the upstream value for the respective river; the average $k_{s n}$ value upstream of the knickpoints is $55.5 \mathrm{~m}^{0.9}$ while downstream of the knickpoints it is $124.2 \mathrm{~m}^{0.9}$. There is a general trend in the downstream $k_{s n}$ data of significantly higher $k_{s n}$ values in the centre of the fault array, with $k_{s n}$ values reaching $>300 \mathrm{~m}^{0.9}$ at $70 \mathrm{~km}$ along strike. In contrast, lower values of channel steepness in the downstream reaches of the rivers are consistently recorded towards the mapped extent of the fault array.

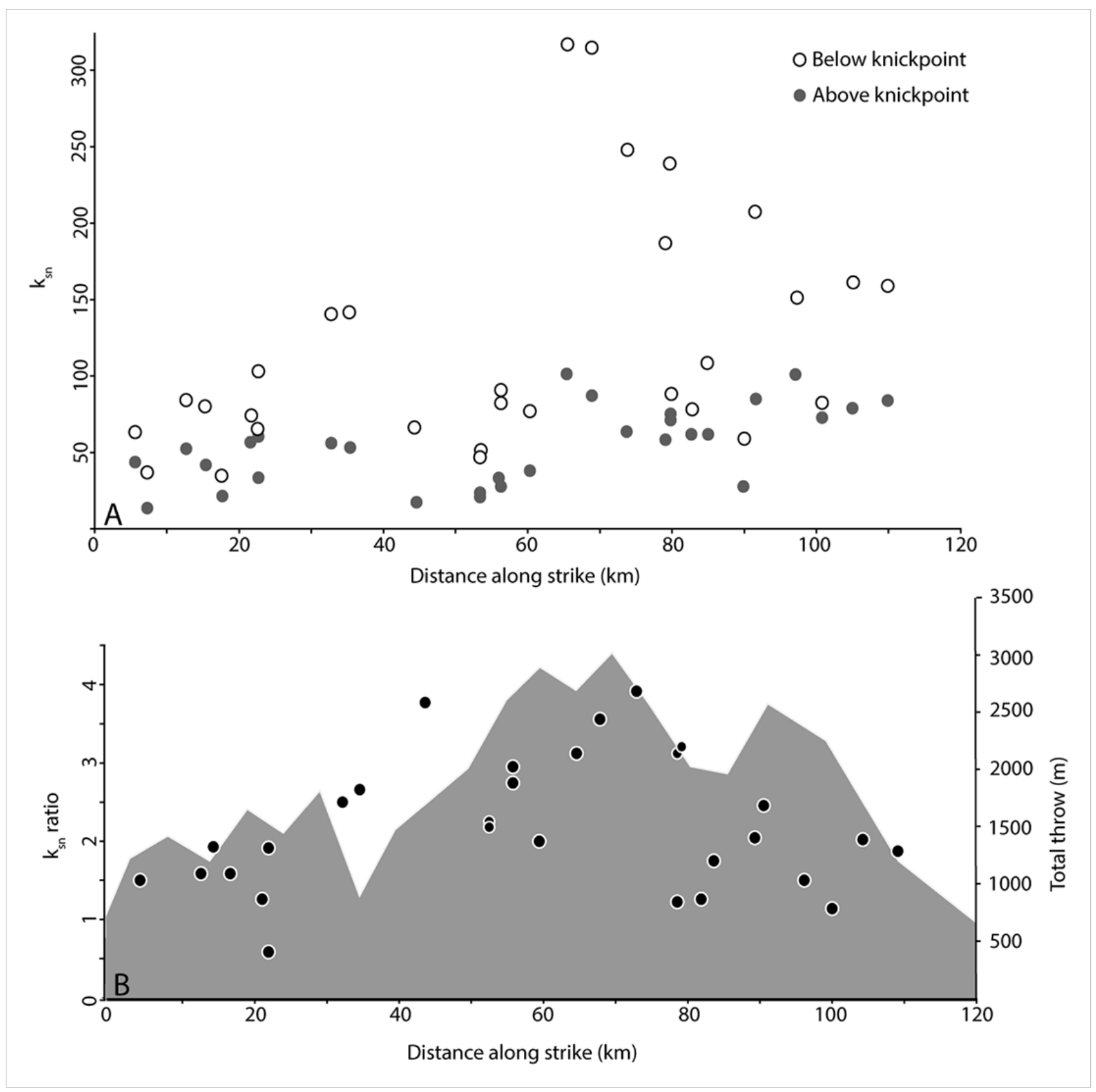


5/18/2017 Normal fault growth and linkage in the Gediz (Alaşehir) Graben, Western Turkey, revealed by transient river long-profiles and slope-break knickpoin...

Open in figure viewer

Along strike plots of concavity normalised steepness index $\left(\mathrm{K}_{\mathrm{sn}}\right)$. The reference concavity used was 0.45 . (A) The $K_{s n}$ values below the knickpoint on each river and the corresponding $K_{s n}$ above the knickpoint. (B) The ratios of $\mathrm{K}_{\mathrm{sn}}$ above and below the knickpoint plotted along strike with back data points. Total fault throw is also shown to illustrate relationships between throw and $\mathrm{K}_{\mathrm{sn}}$ ratios.

The disparities in channel steepness index upstream and downstream of the knickpoints on the channels can be explored by the considering the ratio of the $k_{s n}$ values along the strike of fault (Figure $7(b)$ ). This ratio increases to higher values in the centre of the fault array (i.e. $k_{s n}$ values downstream of the knickpoint within rivers crossing the centre of the active normal fault are larger than the upstream values by a greater amount). The ratio values in the centre of the fault array range from 2.5-3.9, while at the mapped edge of the fault array values of 1.1-2 are typical. These ratios confirm that the disparity in steepness for river reaches upstream and downstream of knickpoints at the centre of the fault array is considerably greater than that found at the tips.

\section{Discussion}

\section{Landscape response to active normal faulting}

Our results show that rivers within the Bozdağ Range typically contain one tectonic knickpoint upstream of the active graben bounding faults, including the streams that drain across the inferred fault segment boundaries (Figure 5), as any lithology-related knickpoints identified (Figure 3) were excluded from the subsequent analysis. There has also not been a regional base level fall or removal of sediment out of the graben valley that could account for the formation of knickpoints. Furthermore, climatic changes are unlikely to be the cause of the knickpoints or their height variation, as precipitation rates do not vary significantly along the Bozdağ Range (Şensoy et al., 2008). Consequently, active faulting is the most likely mechanism for generating the observed knickpoints. The fact they are still observable in the landscape suggests that the rivers draining the Bozdağ Range are recording a transient response to tectonics.

Figure 4 shows that the drainage area of each river is a key determinant of how far the knickpoints have moved upstream. In rivers with greatest drainage area, the incisional wave associated with the knickpoint has migrated further from the fault. The relationship between the upstream channel distance that the knickpoints have migrated, and their catchment drainage area $\left(L \sim A^{0.41}\right)$ is similar to the theoretical predictions from simple stream power models if the knickpoints had all started at the same time $\left(L \sim A^{0.5}\right)$ (Whittaker and Boulton, 2012). Therefore, the simplest explanation for this relationship is that these knickpoints were generated by the same tectonic event. However, we hypothesise that additional factors, such as mapped lithological differences and differing distributions of drainage area with upstream channel distance from the fault may explain the residual signal in Figure 5 and we return to this later (cf. Jansen et al., 2011; Whittaker and Boulton, 2012).

\section{Knickpoints and fault linkage}

The two potential tectonic events that could explain the formation of the knickpoints are therefore either (i) the initiation of active faulting in the Pliocene, or (ii) a subsequent fault slip rate increase along the fault array, due to the interaction and linkage of previously isolated fault segments (Cowie and Roberts, 2001; Densmore et al., 2007; Boulton and Whittaker, 2009).

Mechanically, the linkage process acts to increase fault throw rates due to repeated stress-loading of the centrally-located fault segments by failure of neighbouring strands located along strike (Cowie, 1998a, 
5/18/2017 Normal fault growth and linkage in the Gediz (Alaşehir) Graben, Western Turkey, revealed by transient river long-profiles and slope-break knickpoin...

1998b). Additionally, linked segments are relatively under-displaced for the larger fault structure that they join (Cowie and Roberts, 2001), while larger displacement events occur on longer faults (Dawers and Anders, 1995; Cowie and Roberts, 2001).

The existence of fault linkage has been demonstrated by Çiftçi and Bozkurt (2007) and Kent et al. (2016), and is clearly evidenced by the pattern of throw along strike of the fault, with non-zero values of throw at the fault segment boundaries. The existence of knickpoints in the channels upstream of segment boundaries also suggests that these knickpoints formed due to the linkage. Additionally, two sets of knickpoints in each channel would be expected if fault initiation was being recorded, in addition to a later linkage event (cf. Whittaker and Walker, 2015), and these are not systematically present.

Furthermore, the height of knickpoints along the strike of the fault array mirrors the pattern in throw and footwall relief measurements (Figure 5) with maximum values of both throw and knickpoint height in the centre of the fault. Whittaker et al. (2008) proposed that the magnitude of the difference in throw rate before and after fault linkage was the cause of a similar relationship documented for knickpoints upstream of active faults in the central Italian Apennines.

The interpretation of linkage is consistent with our estimates of normalised channel steepness index, which should reflect variations in relative uplift rate along the strike of the fault (Duvall et al., 2004; Wobus et al., 2006a; Whittaker et al., 2007a; Boulton and Whittaker, 2009; Whittaker and Boulton, 2012). As a channel is perturbed by increased slip on the basin-bounding fault, the river attempts to keep pace with the new rate of throw, leading to the steepening of the channel and the migration of a knickpoint upstream. A higher throw rate should therefore increase the $\mathrm{k}_{\text {sn }}$ value below the knickpoint by a greater amount than a lower throw rate increase, and this is reflected in the data from the Gediz Graben when considered along strike (Figure 5). If it is assumed that uplift rates are linearly proportional to $\mathrm{k}_{\mathrm{sn}}$, (Wobus et al ., 2006a; Kirby and Whipple, 2012; Whittaker, 2012) the ratio of $\mathrm{k}_{\mathrm{sn}}$ upstream and downstream of the knickpoints suggests a maximum relative uplift rate difference of 3-4 in the centre of the fault.

This inference can be independently tested by considering a fault enhancement factor, which quantifies the increase in fault displacement following linkage (Boulton and Whittaker, 2009; Whittaker and Walker, 2015). The enhancement factor, $E$, for any linking fault segment can be calculated by considering the length of the segment pre-linkage $\left(L_{i}\right)$ and the distance between the mid-point of the segment to the mapped extent of the post-linkage array $\left(R_{\mathrm{i}}\right)$ :

display math

This theory assumes that the displacement profile of the fault array is triangular in shape, with a maximum value at the centre, decreasing linearly to zero at the tips. The validity of this approximation has been tested by Cowie and Roberts (2001), who showed that the greatest inaccuracies are at the tips of the fault array, where the absolute fault slip rate increases are in any case small. The lengths of the three fault segments in the Gediz Graben are $41 \mathrm{~km}, 43 \mathrm{~km}, 36 \mathrm{~km}$ from west to east, with a total array length of 120 $\mathrm{km}$. Application of Equation (3) yields a throw enhancement factor of $\sim 3$ at the centre of the array, assuming that the fault strands linked at the same time. This is consistent with the enhancement factor of 3-4 deduced from $\mathrm{k}_{\mathrm{sn}}$ ratios at the centre of the fault system.

Therefore, these data show that: (i) the rivers in the Gediz Graben are undergoing a transient response to active faulting; (ii) this transient response is best explained by an increase in throw rate due to fault linkage; and (iii) ratios of channel steepness and fault interaction theory independently predict a 3-fold increase in throw rate during the linkage event. Below we use these deductions to improve constraints on the slip rate of the graben-bounding fault.

\section{Constraining fault throw rates}


5/18/2017 Normal fault growth and linkage in the Gediz (Alaşehir) Graben, Western Turkey, revealed by transient river long-profiles and slope-break knickpoin...

One caveat of using geological throw data to produce slip-rate estimates along strike of a basin-bounding fault is that the rate derived is time-averaged. Throw rates for the Gediz Fault estimated by Kent et al.

(2016) are based on averages made over 2.6 or 2 Myr. However, linked fault arrays preferentially accumulate throw at the array centre, with minimal changes in throw rates at the tips of the faults (Cowie and Roberts, 2001; Roberts and Michetti, 2004; Whittaker and Walker, 2015). Time-averaged throw rate values at the centre of the Gediz Graben Boundary Fault may therefore under-estimate the present day rates, as they include the slower pre-linkage rate. In contrast, the eastern and western segments of the fault array should have throw rates broadly similar to those that were produced using the time averaged method, given that they are close to the tips of the fault array.

The fact that the knickpoints documented here have likely grown in response to the post-linkage fault throw rate allows us to resolve rates of pre- and post-linkage fault motion, and to deduce the timing of fault linkage, and the post-linkage rates. To do this we: (i) calculate the range of times for which fault acceleration could have occurred, given geological estimates of fault throw (Figure 8 ) and the enhancement factor, $E$, associated with fault linkage event along the array; (ii) compare these with the times and throw rates required for the knickpoints to grow with the measured vertical heights upstream of the fault (cf. Boulton and Whittaker, 2009; Whittaker and Walker, 2015). We use the total throw across the fault to estimate these rates because this is well-constrained (Kent et al., 2016) and because rivers crossing active faults are sensitive to the magnitude of the throw rate difference across the structure. Our analysis, below, also takes account of sediment accumulation in the hanging wall of the basin. 


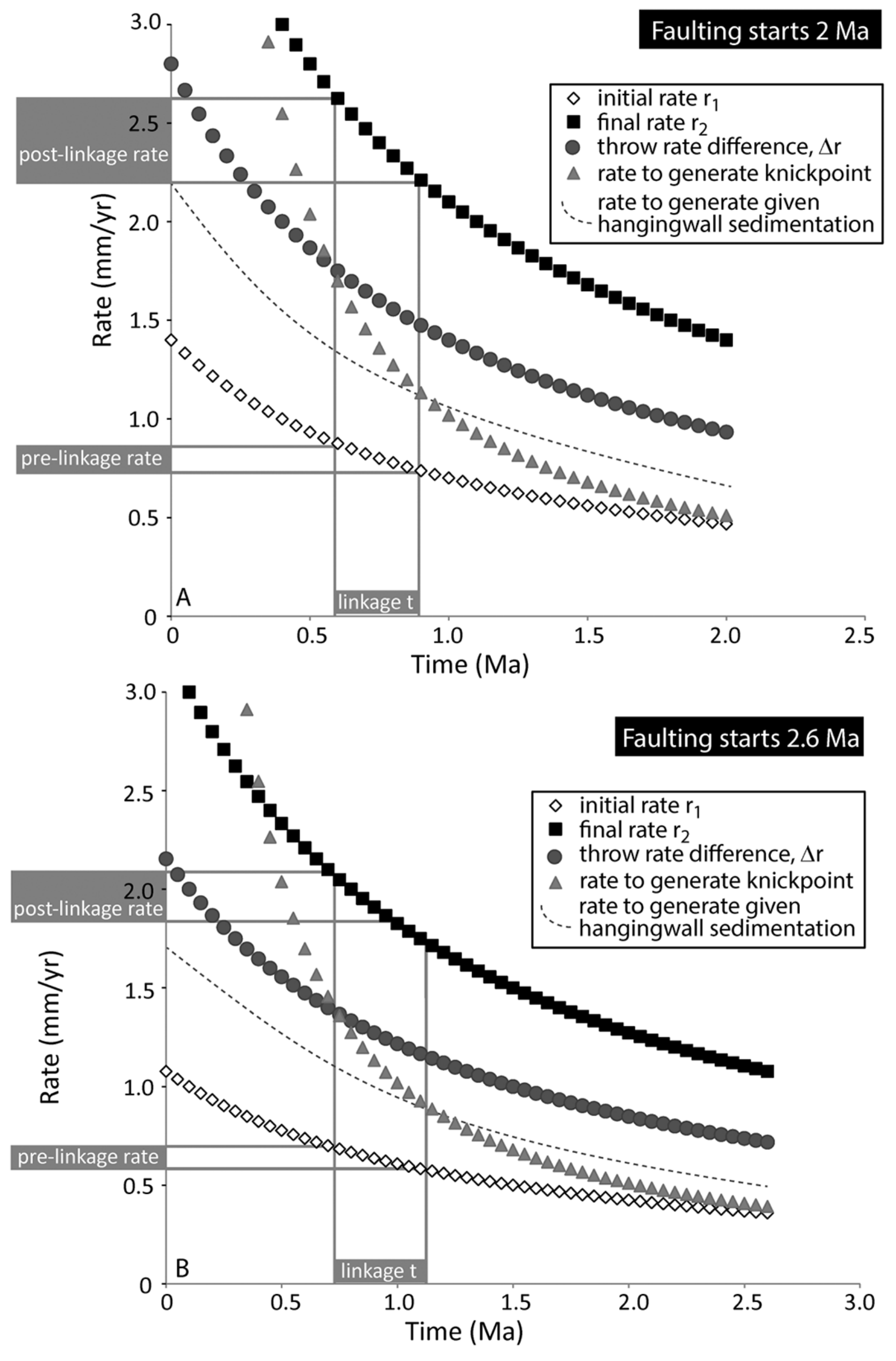


5/18/2017 Normal fault growth and linkage in the Gediz (Alaşehir) Graben, Western Turkey, revealed by transient river long-profiles and slope-break knickpoin...

Open in figure viewer

Calculation of possible throw rates for the centre of the active normal fault array in the Gediz Graben before and after linkage as predicted by Equation (4), for fault initiation at (a) $2 \mathrm{Ma}$ and (b) $2.6 \mathrm{Ma}$. Given a displacement of $T=2800 \mathrm{~m}$, the diamonds show the required throw rate before linkage ( $r 1)$, as a function of time since the throw rate increase (fault linkage [t2]); and squares show the rate after linkage, also as a function of time since throw rate increase. A throw rate enhancement factor of 3 was used. The triangles show the throw rate needed to generate a $1019 \mathrm{~m}$ high knickzone, $\mathrm{r}($ knickzone). The knickpoints respond to relative base level change so the amount of graben fill in the subsiding hanging wall needs to be considered as this can reduce the throw 'perceived' by the river shown by the dashed lines.

For (i) we need an estimate of when high-angle active faulting first occurred in the Gediz Graben. Buscher et al. (2013) and Koçyiğit et al . (1999) infer a similar age for this from sedimentary and structural evidence, so a range from 2 to $2.6 \mathrm{Myr}$ will be used here; since this time, $\sim 2800 \mathrm{~m}$ of throw has accumulated at the centre of the fault (Kent et al., 2016). Given these constraints, all the possible solutions for the following equation are found, which equates the total throw $\left(D_{\mathrm{T}}\right)$, to the slip rates preand post-linkage, $r_{1}$ and $r_{2}$, respectively:

$D_{T}=r_{1} t_{1}+r_{2} t_{2}$

Where $t_{1}$ is the time between fault initiation and fault linkage, and $t_{2}$ is the time since the throw rate increase; $t_{1}+t_{2}$ therefore equals 2.6 or 2 Myr. Additionally, we know that

display math

where $E$ is the throw rate enhancement factor. We use $E=3$ for the centre of the fault. Using these equations, we calculate the range of possible throw rates before and after linkage, each of which is associated with a specific linkage time $t_{2}$ years before present.

We plot the individual combinations of throw rates both pre- (white diamonds) and post-linkage (black squares) for any time, $t$, before present, which satisfy the above constraints for faulting initiation at 2 (Figure 8(a)) and 2.6 Ma (Figure 8(b)), respectively. Without additional information, we do not know which pair of throw rate values is correct. However, the timescale and magnitude of the post-linkage throw rate must be consistent with the knickpoint heights measured in the rivers (Boulton and Whittaker, 2009;

Whittaker and Walker, 2015). Modelling and theoretical studies (Attal et al., 2008; Whittaker et al., 2008) show that the vertical height of a knickpoint, $H$, should scale with the throw rate difference since the fault linkage event. This means that

$H \sim \mathrm{t}_{2}\left(\mathrm{r}_{2}-\mathrm{r}_{1}\right)$

The locus of points satisfying this relation is shown by grey triangles in Figure 8, for the highest knickpoint, right in the centre of the fault array, which is at an elevation of $1019 \mathrm{~m}$ above the fault. As the time to 'grow' the knickpoint should be consistent with the predicted differential throw rate pre- and post- linkage, we can therefore estimate the timing of this event, and the post-linkage rate, $r_{2}$ (cf. Boulton and Whittaker, 2009; Whittaker and Walker, 2015). Our best estimate for the time of linkage is derived from the point at which the knickpoint data set (grey triangles) crosses the throw rate difference data set (red circles). A fault linkage event at 0.6 to $0.75 \mathrm{Ma}$ therefore explains the data well given the fault initiation at 2 to $2.6 \mathrm{Ma}$. However, as the knickpoints grow in response to a relative base level change, consideration needs to be given to the graben fill in the subsiding hanging wall of the fault. This reduces the differential throw rate increase experienced by the river (Whittaker et al., 2007b). The sedimentation rate in the hanging wall of the fault is not known well, but can be approximated by considering 0.35 to $0.5 \mathrm{~mm} / \mathrm{yr}$ of sediment 
5/18/2017 Normal fault growth and linkage in the Gediz (Alaşehir) Graben, Western Turkey, revealed by transient river long-profiles and slope-break knickpoin...

accumulation, to account for the presence of $>1000 \mathrm{~m}$ of sediment filling the graben depo-centre during the time period of faulting (Çiftçi, 2007). This has been represented on Figure 8 as a red dotted line; taking the lower bound, a maximum estimated time for the linkage event is $\sim 0.9$ to $1.2 \mathrm{Ma}$.

The throw rate values yielded by this method are representative of the centre of the fault and are rangemaximum values. We calculate post-linkage throw rates from $2.4-1.9 \pm 0.2 \mathrm{~mm} / \mathrm{yr}$, and pre-linkage rates of $0.6-0.7 \mathrm{~mm} / \mathrm{yr}$ at the centre of the fault array. The values for throw rate along strike between the centre and the mapped extent of the normal faults could be estimated by extrapolating a straight line that joins the peak and minimum values for throw rate, if the distribution of throw rates along strike is modelled as a triangle (cf. Cowie and Roberts, 2001) and are shown in Table 1.

Independent quantitative constraints on the rate of motion along the graben boundary fault are surprisingly rare, although the timing for the onset of fault activity is now reasonably well constrained at $\sim 2$ to $2.6 \mathrm{Ma}$ (Koçyigit et al., 1999; Oner and Dilek, 2011; Buscher et al., 2013). Only Koçyigit et al. (1999) estimates the subsidence rate along the southern margin as $1 \mathrm{~mm} / \mathrm{yr}$ based upon $\sim 2.2 \mathrm{~km}$ of throw. This estimate would equate to a throw rate of $\sim 1.3 \mathrm{~mm} / \mathrm{y}$ using a $1: 3$ ratio of uplift to subsidence along the fault array. Throw rates derived from our analysis of geologic and geomorphic data (Kent et al., 2016) give a similar maximum time-averaged throw rate of $1.4 \mathrm{~mm} / \mathrm{yr}$ at the centre of the fault array. Therefore, the calculated post-linkage throw rate of $c .2 \mathrm{~mm} / \mathrm{yr}$ is consistent as the linkage event results in an acceleration of motion in the centre of the fault array, which would result in an underestimation of present throw-rates when using long-term averaged data.

\section{Constraining knickpoint retreat rates and landscape response times}

Having determined that there has been a tectonic perturbation due to fault linkage in the Gediz Graben at c. $0.8 \mathrm{Ma}$, a significant question is how fast the fluvially-sculpted landscape is responding to the interaction and linkage of the faults. As discussed earlier, as knickpoints retreat upstream, they transmit the relative base-level or uplift rate change to the catchment as a whole. Consequently, knickpoint retreat rates play a fundamental role in determining landscape response times in non-glaciated terrain (Tucker and Whipple, 2002; Harkins et al., 2007; Whittaker et al., 2008; Whittaker and Boulton, 2012).

We calculate retreat rates for knickpoints in the Gediz Graben using their documented position upstream from the fault, assuming they were generated by a fault linkage event at 0.6-1.0 Ma (Figure 9(a)). The lowest average retreat rates are found in the Turgutlu and Alaşehir Segments, with minimum values at each end occurring within the half of the segment nearest to the edge of the fault array. The minimum value within the Turgutlu Segment is $7.6 \mathrm{~mm} / \mathrm{yr}$ with linkage at $600 \mathrm{Ka}$ and $4.3 \mathrm{~mm} / \mathrm{yr}$ with linkage at $1 \mathrm{Ma}$, while the minimum for Alaşehir with linkage at $600 \mathrm{Ka}$ is $4.5 \mathrm{~mm} / \mathrm{yr}$ and with linkage at $1 \mathrm{Ma}$ is $2.7 \mathrm{~mm} / \mathrm{yr}$. The maximum average knickpoint retreat rates are found within the Salihli Segment and are $27.6 \mathrm{~mm} / \mathrm{yr}$ and $16.6 \mathrm{~mm} / \mathrm{yr}$ for linkage at $600 \mathrm{Ka}$ and $1 \mathrm{Ma}$ respectively. 


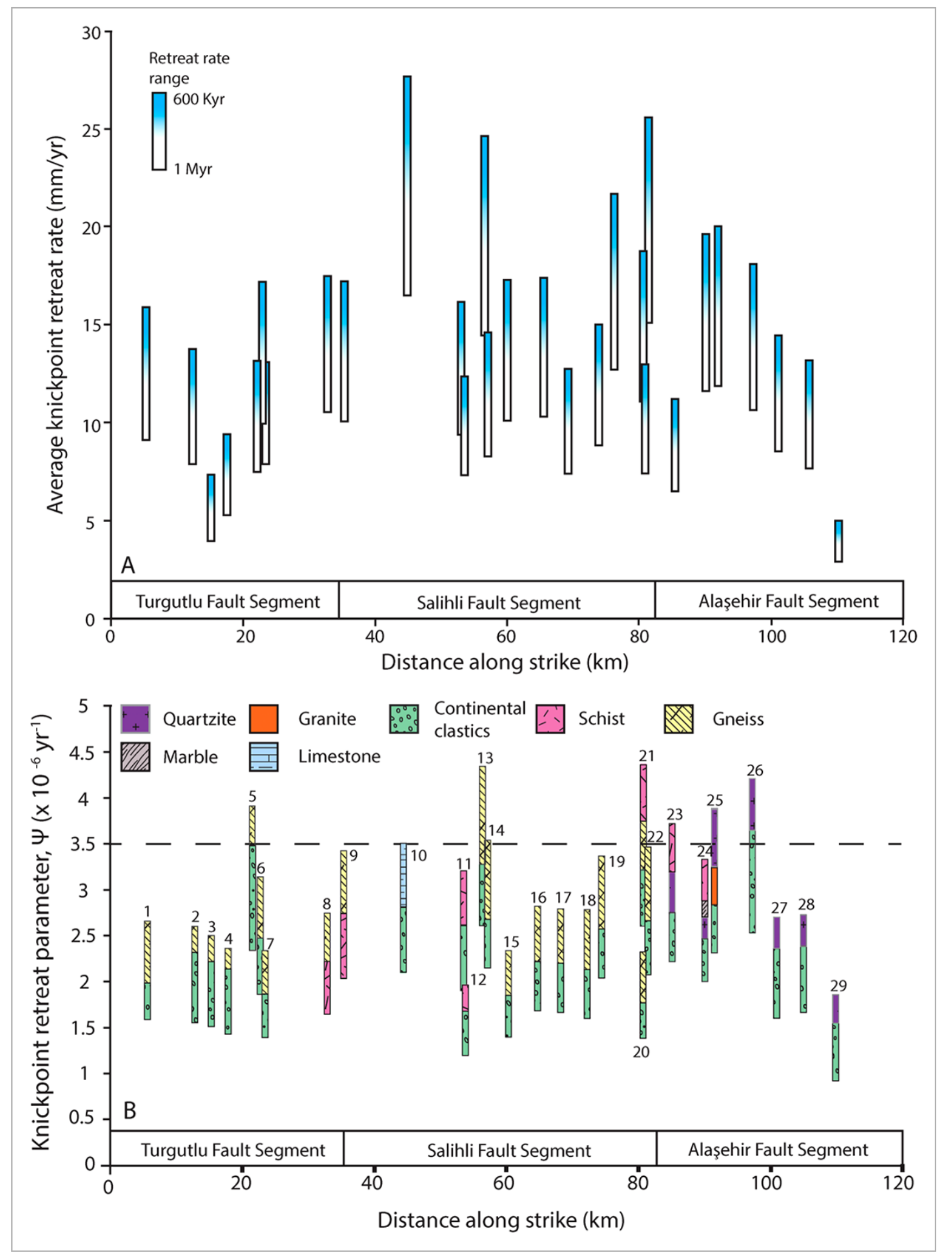

Figure 9.

Open in figure viewer

(a) Time average retreat rates for knickpoints in the Gediz Graben plotted along strike. The range of the values is determined by the calculated range for time for fault linage induced 
5/18/2017 Normal fault growth and linkage in the Gediz (Alaşehir) Graben, Western Turkey, revealed by transient river long-profiles and slope-break knickpoin...

knickpoint initiation of 1 to $0.6 \mathrm{Myr}$. (b) The knickpoint retreat parameters for knickpoints in the Gediz Graben plotted along strike, showing a bar range based on an oldest and youngest age for linkage at 1 to $0.6 \mathrm{Myr}$. The fill of the bars is determined by the lithologies that the knickpoints in the rivers have retreated through, up to the current position of the knickpoint in the channel.

[Colour figure can be viewed at wileyonlinelibrary.com]

\section{Control of mapped lithology on knickpoint propagation}

There is considerable intra-graben variation in knickpoint retreat rates that could be explained by the range of lithologies forming Bozdağ Range (Figure 2). All but two of the 29 rivers studied have $>1.5 \mathrm{~km}$ of continental clastic sediments directly upstream of the fault. These sediments are generally not strongly lithified and potentially easily erodible (Purvis and Robertson, 2005; Kent, 2015). These units are juxtaposed against the metamorphic basement forming the higher elevations of the Bozdağ Range, including schists and gneisses with additional granite, phyllite and quartzite (Figure 2). We hypothesise that these differences in mapped lithology could influence knickzone retreat rates between the study rivers (Goldrick and Bishop, 1995; Anthony and Granger, 2007; Bursztyn et al., 2015; Kent, 2015).

To investigate intra-graben variation in knickpoint retreat, $\psi$ is plotted along strike of the Gediz Graben Boundary Fault, using a bar whose percentage fill is determined by the up-channel distribution of mapped lithologies that the knickpoints have retreated through, to reach their current positions (Figure 9(b)). The mapped formations may disguise a range of lithological resistances to fluvial erosion but for our purposes serve as a first-order approximation of potential differences in bedrock erodibility (cf. Bursztyn et al., 2015). Maximum and minimum values are determined by the fault linkage times deduced above. The dashed line shows catchments with $\psi>3.5 \times 10^{-6} \mathrm{yr}^{-1}$, representing the upper $20 \%$ of retreat values, assuming a linkage event at 0.6 Ma. River 5, within the Turgutlu fault segment lies over this line. The knickpoint has retreated through a channel that, by length, is around two-thirds clastic sediments and onethird gneiss. However, the distribution of gneiss and sediments in the rest of the rivers in the Turgutlu segment is similar, so mapped lithology does not immediately provide an explanation. Within the Salihli Segment three rivers have high $\psi$ : Rivers 13 and 14 have knickpoints that have retreated through almost two-thirds gneiss and around $1 / 3$ sediments. River 21 has a knickpoint that has retreated through one-third each of sediments, gneiss and schist; these lithological percentages do not differ significantly from those in the rivers with smaller $\psi$ values. In the Alaşehir segment, rivers 23, 25 and 26 all have $\psi$ values higher than $3.5 \times 10^{-6}$. Each has a knickpoint that has retreated through around one-third quartzite with various proportions of clastic sediments and schist, and in one river about one-quarter granite. Again, these percentages are not very different from other rivers draining across this fault segment.

This analysis does not rule out lithology as a cause of the variation; it simply means the differences cannot be attributed to mapped lithologies in a trivial way. Bedrock erodibility is a function of many parameters, including intrinsic rock hardness, weathering, and the spacing, orientation, and size of joints. We argue that capturing this detail from regional-scale geological maps is difficult and this study underlines the complexity of converting mapped lithology to bedrock erodibility and hence its influence on $\psi$ in Equation (1). A key challenge for the future is to constrain knickpoint retreat in individual study catchments as a function of bedrock erodibility, quantified by using appropriate physical measurements of rock strength and fracture density (cf. Bursztyn et al., 2015).

\section{Comparison of knickpoint retreat rates}

The knickpoint migration rates calculated here are also comparable with those quoted in other studies over the same time periods. Jansen et al. (2011) calculated knickpoint retreat rates in response to glacioisostatic rebound of $20 \mathrm{~mm} / \mathrm{yr}$ to $200 \mathrm{~mm} / \mathrm{yr}$ in study sites in France. Hayakawa and Matsukura (2003) calculated retreat rates of $1.3 \mathrm{~mm} / \mathrm{yr}$ to $270 \mathrm{~mm} / \mathrm{yr}$ for Japanese rivers responding to ongoing 
5/18/2017 Normal fault growth and linkage in the Gediz (Alaşehir) Graben, Western Turkey, revealed by transient river long-profiles and slope-break knickpoin...

tectonic uplift. Retreat rates upstream of active normal faults range from 1.4 to $10.7 \mathrm{~mm} / \mathrm{yr}$ in the Central Apennines of Italy (Whittaker et al., 2008) to just $0.3 \mathrm{~mm} / \mathrm{yr}$ to $2.7 \mathrm{~mm} / \mathrm{yr}$ in the Hatay Graben of Turkey (Whittaker and Boulton, 2012). At face value, knickpoints upstream of faults in the Gediz graben are moving up to 2.5 times faster than those in the Central Apennines and 10 times faster than those in the Hatay Graben. However, average rate differences also reflect significant variations in catchment size. We therefore estimate the drainage area normalised retreat rate, $\psi$, for a unit stream power model (Equation (1)) for all the rivers in the Gediz Graben (Table 1) by solving iteratively the following relation for the upstream position of the knickpoint, $L_{k}$ over the time period $t_{2}$ :

$L_{\text {knick }}=L_{\text {fault }}-\left(\psi \sqrt{ } A_{f(L)}\right) / t_{2}$

This equation takes into account the decrease in drainage area with upstream distance, which leads to a deceleration of knickpoint retreat over time (Whittaker et al., 2008). The best-fit $\psi$ values obtained are plotted against fault throw rate, to enable comparison of rivers with different drainage areas crossing active faults in the Hatay Graben and the Central Apennines (Figure 10). 


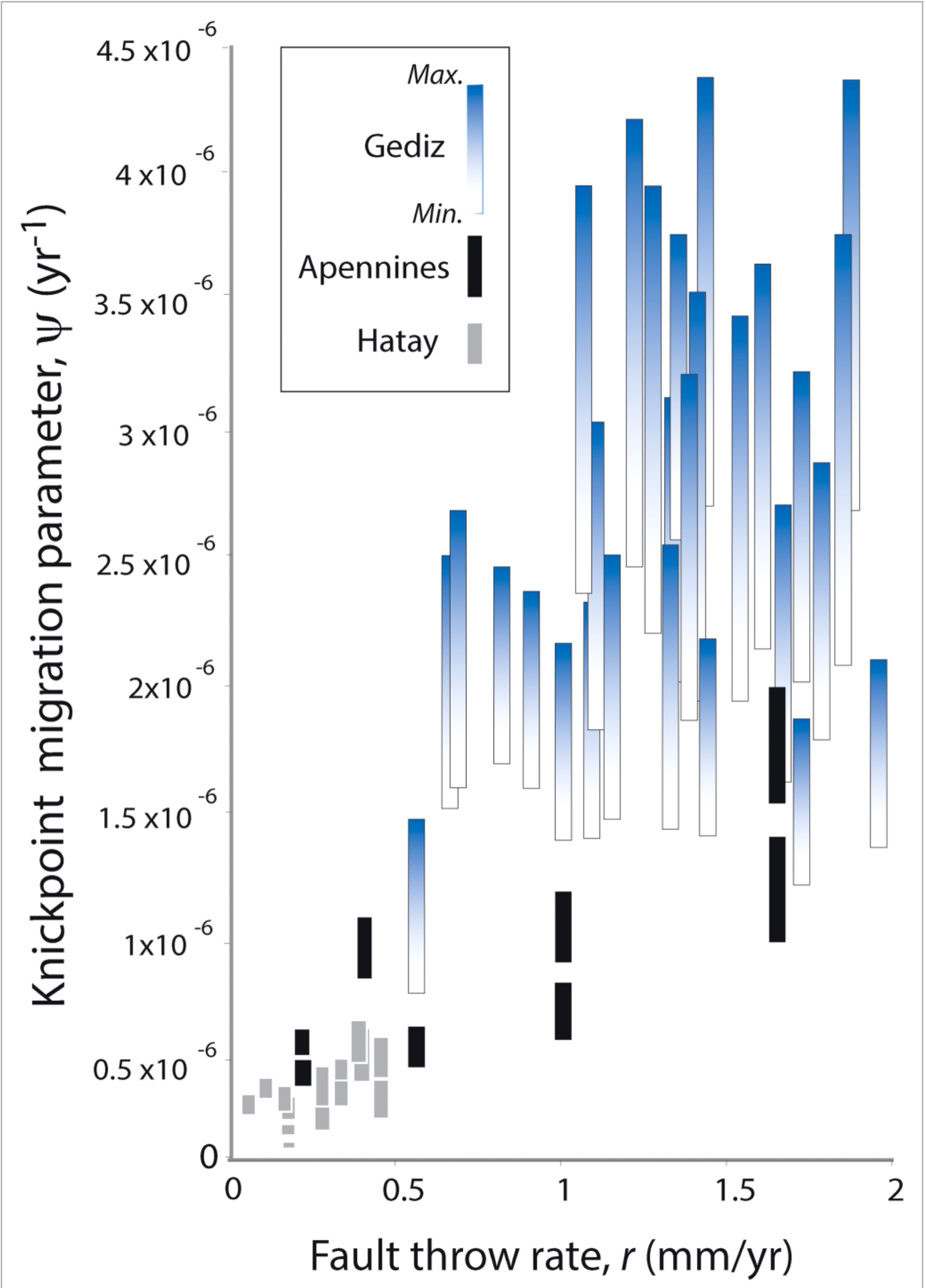

Figure 10.

Open in figure viewer 
5/18/2017 Normal fault growth and linkage in the Gediz (Alaşehir) Graben, Western Turkey, revealed by transient river long-profiles and slope-break knickpoin...

The knickpoint retreat parameter for the Gediz graben plotted against throw rate with maximum and minimum values based on linkage between 1 and 0.6 myr. The data for The Italian

Apennines and Hatay Graben, Turkey, are included as black and grey bars. Additional data from Whittaker et al. (2008) and Whittaker and Boulton (2012). [Colour figure can be viewed at wileyonlinelibrary.com]

The drainage area normalised knickpoint retreat parameter $(\psi)$ varies by a factor of $c .6$, between $9.2 \times 10^{-7} \mathrm{yr}^{-1}$ for a linkage time of $1 \mathrm{Ma}$ to $4.3 \times 10^{-6} \mathrm{yr}^{-1}$ for linkage at $0.6 \mathrm{Ma}$ (Figure 10). These $\psi$ values can be used to calculate an effective landscape response time to active faulting by considering the time taken for a knickpoint to propagate to the headwaters of the catchment. Using a theoretical river with a $50 \mathrm{~km}^{2}$ drainage area, an average value appropriate for the Gediz Graben channels, and assuming that such a catchment obeys Hack's scaling law (Hack, 1957), we calculate (using Equation (1)) that it would take between 1.6 Myr and 2.7 Ma to propagate a knickpoint to within $1 \mathrm{~km}$ of the headwaters. These results therefore confirm the suggestion that rivers record tectonic information in their long profiles over geologic time periods (cf. Whittaker et al., 2007a; Roberts and White, 2010).

Although normalising by $A$ does explain some of the absolute differences in knickpoint retreat rate, the 6fold variation in $\psi$ in the Gediz Graben shows that drainage area is not the only influence on the knickpoint retreat rate. Other parameters that may influence these rates include lithology, sediment flux (Jansen et al., 2011), dynamic channel narrowing effects (Attal et al., 2011) and channel gradient, if $n$ $>1$ in the stream power erosion law (Equation (1)). Local climate differences in the Gediz Graben can be ruled out immediately and existing work suggests that stream-power driven erosion in the area is consistent with $n \sim 1$ (Kent, 2015). Moreover, Whittaker and Boulton (2012) suggested that knickpoint retreat rates are sensitive to fault throw rates because fault-driven channel steepening leads to a predictable dynamic channel narrowing effect.

Figure 10 shows there is a trend towards higher values for $\psi$ at higher throw rates, with average values increasing from $\sim 1 \times 10^{-6} \mathrm{yr}^{-1}$ to $>3 \times 10^{-6} \mathrm{yr}^{-1}$ across the throw rate range. We do not have width data for all these channels, but we hypothesise that channel narrowing effects, similar to those documented by Whittaker and Boulton (2012) apply here also. When these data are compared to existing studies of knickpoints upstream of normal faults in the Hatay Graben of Turkey and in the Central Apennines of Italy, the most significant observation is that $\psi$ is greater and therefore landscape response times faster in the Gediz Graben than in the other two study areas. The lowest $\psi$ values for the Gediz rivers are as large as the highest values for the Apennines, and on average $\psi$ values are at least a factor of two larger than for Italian examples. All the $\psi$ values for the Gediz Graben are significantly greater than those from the Hatay Graben, with a typical difference of a factor of 7.

Climate-controlled differences in precipitation-driven discharge, $Q$, could be one explanation for these effects, because we normalise retreat rate parameters by drainage area, $A$, which is only a proxy for $Q$ (Attal et al., 2008). The climate along the Bozdağ range today is uniform and moderately arid with modern precipitation rates varying from $500 \mathrm{~mm} / \mathrm{yr}$ to $1000 \mathrm{~mm} / \mathrm{yr}$ in the highest parts of the range (Şensoy et al ., 2008), while in the Apennines the precipitation varies between $750 \mathrm{~mm} / \mathrm{yr}$ in the city of L'Aquilla, to $1500 \mathrm{~mm} / \mathrm{yr}$ in the high Apennines (Whittaker et al., 2008). In the Hatay Graben, annual precipitation varies between $500 \mathrm{~mm} / \mathrm{yr}$ and $1500 \mathrm{~mm} / \mathrm{yr}$ (Whittaker and Boulton, 2012). Consequently, present-day precipitation data cannot explain the differences in $\psi$ between the areas. During Pleistocene glacial episodes, the Hatay Graben was twice as dry as at the present, while Central Apennines was 2-4 times wetter; this difference accounted for the two-fold difference drainage area normalised knickpoint retreat rate documented by Whittaker and Boulton (2012). Data suggests that a 4- fold increase in precipitation rate within the Gediz Graben is the maximum possible difference that could have occurred in the last $5 \mathrm{Myr}$ (Eronen et al., 2011). This gives a maximum past annual precipitation of around 3000 $\mathrm{mm} / \mathrm{yr}$ for the Gediz Graben, values similar to the Italian Apennines. Consequently, climate could explain 
5/18/2017 Normal fault growth and linkage in the Gediz (Alaşehir) Graben, Western Turkey, revealed by transient river long-profiles and slope-break knickpoin...

differences in retreat rates and landscape response times between the Turkish study areas, but it does not explain differences in retreat rates between the Gediz Graben and Central Apennines.

\section{Conclusions}

Rivers draining across the Gediz Graben Boundary Fault each contain knickpoints, which we conclude were generated by active normal faulting and specifically, an increase in fault throw rates during the Pleistocene. We show that knickpoint heights along the fault trace vary systematically with respect to both fault throw and footwall relief, and we deduce that these knickpoints were caused by linkage of the three main fault segments of the high-angle graben-bounding normal fault at $c .0 .8 \mathrm{Myr}$. The linkage event produced a fault enhancement factor of 3 at the centre of the array, and we use this information to quantify the maximum post-linkage throw rate to be $2.4 \pm 0.2 \mathrm{~mm} / \mathrm{yr}$ to $1.85 \pm 0.15 \mathrm{~mm} / \mathrm{yr}$ given fault initiation times of 2 and $2.6 \mathrm{Ma}$, respectively. This compares with a pre-linkage rate of 0.6 to $0.7 \mathrm{~mm} / \mathrm{yr}$ for the central fault segment. Given that earthquakes of up to $M_{w} 7.6$ could be expected in this region (Kent et al., 2016), the linkage of the faults likely increased the frequency and magnitude of significant seismic activity in the Graben.

Knickpoints upstream of the rivers are retreating at maximum time-averaged rates of 4.5 to $28 \mathrm{~mm} / \mathrm{yr}$, if the fault interaction event is as young as $0.6 \mathrm{Myr}$. Consequently, the fluvial landscape response time implied for these rivers is between 1.6 Ma and 2.7 Ma. When knickpoint retreat rate is normalised for its dependence on upstream drainage area, we find there are still significant differences in the areanormalised knickpoint retreat parameter, $\psi$, along strike within the Gediz Graben. There is a trend towards higher retreat rates with higher throw rates, which may be driven by dynamic channel narrowing effects (cf. Attal et al., 2008; Whittaker and Boulton, 2012). Lithology is diverse in the footwall of the fault, but variations in the mapped rock units do not link simply to intra-graben variations in $\psi$.

Finally, our analysis shows that knickpoints upstream of active faults in the Gediz Graben are retreating twice as fast on average than data for normal faults in the Central Apennines of Italy (Whittaker et al., 2008) and up to seven times as fast as knickpoints in the Hatay Graben, Turkey (Boulton and Whittaker, 2009; Whittaker and Boulton, 2012). Differences in long term precipitation explain the variation in $\psi$ between the Turkish study sites, and we hypothesise that bedrock erodibility differences between the limestone footwalls of the Apennine examples, and the clastic sediments and schists in the footwall of the Gediz Fault explain the latter observation.

\section{Acknowledgments}

This work forms part of EKs PhD research funded by the School of Geography, Earth and Environmental Sciences, Plymouth University. We thank the editors, Taylor Schildgen and an anonymous reviewer for comments that have clarified and improved the paper. 


\section{References}

Aktug B, Nocquet JM, Cingöz A, Parsons B, Erkan Y, England P, Lenk O, Gürdal MA, Kilicoglu A, Akdeniz H, Tekgül A. 2009. Deformation of western Turkey from a combination of permanent and campaign GPS data: Limits to block-like behavior. Journal of Geophysical Research: Solid Earth (1978-2012), 114(B10).

Anders, A., Speigelman, M. and Rodgers, D., 1993. The growth of fault bonded tilt blocks. Tectonics, 12, 1451-1459.

Anthony DM, Granger DE. 2007. An empirical stream power formulation for knickpoint retreat in Appalachian Plateau fluviokarst. Journal of Hydrology 343(3): 117-126.

Arpat E, Bingöl E. 1969. Ege Bölgesi graben sisteminin gelişimi üzerine düşünceler. MTA Dergisi 73: 1-8.

Attal M, Tucker GE, Whittaker AC, Cowie PA, Roberts GP. 2008. Modelling fluvial incision and transient landscape evolution: influence of dynamic channel adjustment. Journal Geophysical Research: Earth Surface 113, F03013. doi:10.1029/2007JF000893.

Attal M, Cowie PA, Whittaker AC, Hobley D, Tucker GE, Roberts GP. 2011. Testing fluvial erosion models using the transient response of bedrock rivers to tectonic forcing in the Apennines, Italy. Journal of Geophysical Research: Earth Surface (2003-2012), 116(F2).

Baldwin JA, Whipple KX, Tucker GE. 2003. Implications of the shear stress river incision model for the timescale of post-orogenic decay of topography. Journal of Geophysical Research: Solid Earth (1978-2012), 108(B3).

Barka A, Reilinger R. 1997. Active tectonics of the Eastern Mediterranean region: deduced from GPS, neotectonic and seismicity data. Annals of Geophysics, 40(3). 
Berlin MM, Anderson RS, 2007. Modeling of knickpoint retreat on the Roan Plateau, western Colorado. Journal of Geophysical Research 112: F03S06. Doi:10.1029/2006JF000553

Bishop P, Hoey TB, Jansen JD, Artza IL. 2005. Knickpoint recession rate and catchment area: the case of uplifted rivers in Eastern Scotland. Earth Surf. Processes 30: 767-778.

Boulton SJ, Whittaker AC. 2009. Quantifying the slip-rates, spatial distribution and evolution of active normal faults from geomorphic analysis: Field examples from an oblique-extensional graben, Southern Turkey. Geomorphology 104: 299-316. doi: 10.1016/j.geomorph.2008.09.007.

Boulton SJ, Stokes M, Mather AE. 2014. Transient fluvial incision as an indicator of active faulting and Plio-Quaternary uplift of the Moroccan High Atlas. Tectonophysics 633: 16-33.

Bozkurt E, 2003. Origin of NE-trending basins in western Turkey. Geodinamica Acta, 16(2), 61-81.

Bozkurt E, Sözbilir H. 2004. Tectonic evolution of the Gediz Graben: field evidence for an episodic, two-stage extension in western Turkey. Geological Magazine 141(01): 63-79.

Bozkurt E, Mittwede SK. 2005. Introduction: Evolution of continental extensional tectonics of western Turkey. Geodinamica Acta 18(3-4): 153-165.

Bursztyn N, Pederson JL, Tressler C, Mackley RD, Mitchell KJ. 2015. Rock strength along a fluvial transect of the Colorado Plateau-quantifying a fundamental control on geomorphology. Earth and Planetary Science Letters 429: 90-100.

Buscher JT, Hampel A, Hetzel R, Dunkl I, Glotzbach C, Struffert A, Akal C, Rätz, M. 2013. Quantifying rates of detachment faulting and erosion in the central 
Menderes Massif (western Turkey) by thermochronology and cosmogenic 10Be. Journal of the Geological Society 170(4): 669-683.

Çemen I, Catlos EJ, Göğüs O, Özerdem C, 2006. Postcollisional extensional tectonics and exhumation of the Menderes massif in the Western Anatolia extended terrane, Turkey. Geological Society of America Special Papers, 409, 353-379.

Ciftci NB. 2007. Geological evolution of the Gediz graben, SW Turkey: Temporal and spatial variation of the graben. Ph. D. thesis, Middle East Technical University, Ankara, Turkey.

Çiftçi NB, Bozkurt E. 2007. Anomalous stress field and active breaching at relay ramps: a field example from Gediz Graben, SW Turkey. Geological Magazine 144: 687-699.

Çiftçi NB, Bozkurt E. 2009a. Pattern of normal faulting in the Gediz Graben, SW Turkey. Tectonophysics 473(1): 234-260.

Çiftçi NB, Bozkurt E. 2009b. Evolution of the Miocene sedimentary fill of the Gediz Graben, SW Turkey. Sedimentary Geology 216(3): 49-79.

Çiftçi NB, Bozkurt E. 2010. Structural evolution of the Gediz graben, SW Turkey: Temporal and spatial variation of the graben basin: Basin Research 22: 846-873.

Cook KL, Whipple KX, Heimsath AM, Hanks TC, 2009. Rapid incision of the Colorado River in Glen Canyon - insights from channel profiles, local incision rates, and modelling of lithologic controls. Earth Surface Processes and Landforms 34: 994 - 1010.

Cowie PA. 1998a. A healing-reloading feedback control on the growth rate of seismogenic faults. Journal of Structural Geology 20(8): 1075-1087. 
Cowie PA. 1998b. Normal fault growth in three dimensions in continental and oceanic crust. Geophysical Monograph-American Geophyscial Union, 106: 325348.

Cowie PA, Roberts GP. 2001. Constraining slip rates and spacings for active normal faults. Journal of Structural Geology 23(12): 1901-1915.

Cowie PA, Attal M, Tucker GE, Whittaker AC, Naylor M, Ganas A, Roberts GP. 2006. Investigating the surface process response to fault interaction and linkage using a numerical modelling approach. Basin Research 18(3): 231-266.

Crosby BT, Whipple KX, 2006. Knickpoint initiation and distribution within fluvial networks, 236 waterfalls in the Waipaoa River, North Island, New Zealand. Geomorphology 82: 16-38.

Crosby BT, Whipple KX, Gasparini NM, Wobus CW. 2007. Formation of fluvial hanging valleys: Theory and simulation. Journal of Geophysical Research: Earth Surface (2003-2012), 112(F3).

Dawers NH, Anders MH. 1995. Displacement-length scaling and fault linkage. Journal of Structural Geology 17(5): 607-614.

Densmore AL, Gupta S, Allen PA, Dawers NH. 2007. Transient landscapes at fault tips. Journal of Geophysical Research: Earth Surface (2003-2012), 112(F3).

Dewey JF, Şengör AC. 1979. Aegean and surrounding regions: complex multiplate and continuum tectonics in a convergent zone. Geological Society of America Bulletin 90(1): 84-92.

Duvall A, Kirby E, Burbank D. 2004. Tectonic and lithologic controls on bedrock channel profiles and processes in coastal California. Journal of Geophysical Research: Earth Surface (2003-2012): 109(F3). 
Eyidoğan H. Jackson J. 1985. A seismological study of normal faulting in the Demirci, Alaşehir and Gediz earthquakes of 1969-70 in western Turkey: Implications for the nature and geometry of deformation in the continental crust. Geophysical Journal International, 81(3): 569-607.

Eronen JT, Micheels A, Utescher T. 2011. A comparison of estimates of mean annual precipitation from different proxies: a pilot study for the European Neogene. Evolutionary Ecology Research 13(8): 851-867.

Ferrier KL, Huppert KL, Perron JT. 2013. Climatic control of bedrock river incision. Nature 496(7444): 206-209.

Gasparini NM, Whipple KX. 2014. Diagnosing climatic and tectonic controls on topography: Eastern flank of the northern Bolivian Andes. Lithosphere 6(4): 230250.

Gasparini NM, Bras RL, Whipple KX. 2006. Numerical modelling of non-steady-state river profile evolution using a sediment-flux-dependent incision model, in Tectonics, Climate and Landscape Evolution, Willet, S (Ed). Geological Society of America Special Paper 398: 127-141.

Goldrick G, Bishop P. 2007. Regional analysis of bedrock stream long profiles: evaluation of Hack's SL form, and formulation and assessment of an alternative (the DS form). Earth Surface Processes and Landforms 32(5): 649-671.

Guidoboni E, Comastri A. 2005. Catalogue of Earthquakes and Tsunamis in the Mediterranean Area from the 11th to the 15th Century. SGA, Italy.

Guidoboni E, Comastri A, Traina G. 1994. Catalogue of Ancient Earthquakes in the Mediterranean Area up to the 10th Century. SGA, Italy. 
Goren L, Fox M, Willett SD. 2014. Tectonics from fluvial topography using formal linear inversion: Theory and applications to the Inyo Mountains, California. Journal of Geophysical Research: Earth Surface 119(8): 1651-1681.

Hack JT. 1957. Studies of longitudinal stream profiles in Virginia and Maryland. USGS Report No. 294-B.

Harkins N., Kirby E., Heimsath A., Robinson R, Resier U. 2007. Transient fluvial incision in the headwaters of the Yellow River, northeastern Tibet, China. Journal of Geophysical Research 112: F03S04. doi:10.1029/2006JF000570.

Hayakawa Y., Matsukura Y. 2003. Recession rates of waterfalls in Boso Peninsula, Japan, and a predictive equation. Earth Surface Processes and Landforms 28(6): $675-684$

Haviv I., Enzel Y., Whipple KX., Zilberman E., Matmon A., Stone J., Fifield K. L. 2010. Evolution of vertical knickpoints (waterfalls) with resistant caprock: Insights from numerical modeling. Journal of Geophysical Research: Earth Surface (20032012): 115(F3).

Hopkins MC, Dawers NH. 2015. Changes in bedrock channel morphology driven by displacement rate increase during normal fault interaction and linkage. Basin Research 27(1): 43-59.

Jansen JD, Fabel D, Bishop P, Xu S, Schnabel C, Codilean AT. 2011. Does decreasing paraglacial sediment supply slow knickpoint retreat? Geology 39(6): 543-546.

Kent E. 2015. The relationship between active faulting and fluvial geomorphology: $A$ case study in the Gediz Graben, Turkey. Ph.D thesis, Plymouth University. 
Kent E, Boulton SJ, Stewart IS, Whittaker AC, Alçiçek MC, 2016. Geomorphic and geologic constraints on the active normal faulting of the Gediz (Alaşehir) Graben, Western Turkey. Journal of the Geological Society, London 173: 666-678.

Kirby E, Whipple KX, 2012. Expression of active tectonics in erosional landscapes. Journal of Structural Geology 44: 54-75.

Kirby E, Whipple KX, Tang W, Chen Z, 2003. Distribution of active rock uplift along the eastern margin of the Tibetan Plateau: inferences from bedrock channel longitudinal profiles. Journal of Geophysical Research 108 (B4): 2217. doi: 10.129/2001JB000861.

Kirby E, Whipple K, Harkins, N. 2008. Topography reveals seismic hazard. Nature Geoscience 1(8): 485-487.

Koçyigit A, Yusufoglu H, Bozkurt E. 1999. Discussion on evidence from the Gediz Graben for episodic two-stage extension in western Turkey. Journal of the Geological Society, London 156: 1240-1242.

Merritts D, Bull WB. 1989. Interpreting Quaternary uplift rates at the Mendocino triple junction, northern California, from uplifted marine terraces. Geology 17(11): 10201024.

Miller SR, Baldwin SL, Fitzgerald PG. 2012. Transient fluvial incision and active surface uplift in the Woodlark Rift of eastern Papua New Guinea. Lithosphere 4: 131-149. doi:10.1130/L135.1

Mudd SM, Attal M, Milodowski DT, Grieve SW, Valters DA. 2014. A statistical framework to quantify spatial variation in channel gradients using the integral method of channel profile analysis. Journal of Geophysical Research: Earth Surface 119(2): 138-152. 
Oner Z, Dilek Y. 2011. Supradetachment basin evolution during continental extension: The Aegean province of western Anatolia, Turkey. Geological Society of America Bulletin 123(11-12): 2115-2141.

Ouimet WB, Whipple KX, Granger DE. 2009. Beyond threshold hillslopes: Channel adjustment to base-level fall in tectonically active mountain ranges. Geology 37(7): 579-582.

Pederson JL, Tressler C. 2012. Colorado River long-profile metrics, knickzones and their meaning. Earth and Planetary Science Letters 345: 171-179.

Purvis M, Robertson AHF. 2004. A pulsed extension model for the Neogene-Recent E-W-trending Alaşehir Graben and the NE-SW-trending Selendi and Gördes Basins, western Turkey. Tectonophysics 391(1): 171-201.

Purvis M, Robertson AHF. 2005. Sedimentation of the Neogene-Recent Alaşehir (Gediz) continental graben system used to test alternative tectonic models for western (Aegean) Turkey. Sedimentary Geology 173(1): 373-408.

Roberts GG, White N. 2010. Estimating uplift rate histories from river profiles using African examples. Journal of Geophysical Research: Solid Earth (1978-2012), 115(B2).

Roberts GP, Michetti AM. 2004. Spatial and temporal variations in growth rates along active normal fault systems: an example from the Lazio-Abruzzo Apennines, central Italy. Journal of Structural Geology 26(2): 339-376.

Royden L, Taylor Perron J. 2013. Solutions of the stream power equation and application to the evolution of river longitudinal profiles. Journal of Geophysical Research: Earth Surface 118(2): 497-518. 
Rudge JF, Roberts GG, White N, Richardson CN. 2015. Uplift histories of Africa and Australia from linear inverse modeling of drainage inventories. Journal of Geophysical Research: Earth Surface 120, 894-914.

Sengör AMC, Satir M, Akkök R. 1984. Timing of tectonic events in the Menderes Massif, western Turkey: Implications for tectonic evolution and evidence for Pan-African basement in Turkey. Tectonics 3(7): 693-707.

Şensoy S, Demircan M, Ulupınar Y, Balta İ. Climate of Turkey. 2008. Turkish State Meteorological Service, Ankara.

Seyitoğlu G, Tekeli O, Çemen I, Sen S, \& Işik V. 2002. The role of the flexural rotation/rolling hinge model in the tectonic evolution of the Alasehir graben, western Turkey. Geological Magazine 139(01): 15-26.

Seyitoğlu G, Işık V, Cemen I. 2004. Complete Tertiary exhumation history of the Menderes massif, western Turkey: an alternative working hypothesis. Terra Nova 16(6): 358-364

Snyder NP, Whipple KX, Tucker GE, Merrits DJ, 2000. Landscape evolution to tectonic forcing: digital elevation model analysis of stream profiles in the Mendocino triple junction region, northern California. Geological Society of America Bulletin 112: 1250-1263.

Stephenson SN, Roberts GG, Hoggard MJ, Whittaker AC. 2014. A Cenozoic uplift history of Mexico and its surroundings from longitudinal river profiles. Geochemistry, Geophysics, Geosystems 15(12): 4734-4758.

Stock JD, Montgomery DR. 1999. Geologic constraints on bedrock river incision using the stream power law: Journal of Geophysical Research B: Solid Earth 104(3): 4983-4993. 
ten Veen, JH, Boulton SJ, Alçiçek MC, 2009. Ocean closure, post-orogenic collapse and neotectonics in the Neotethys realm: the importance of kinematic decoupling and inherited structural grain in S.W. Anatolia (Turkey). Tectonophysics 473: 261281.

Tucker GE, Whipple KX, 2002. Topographic outcomes predicted by stream erosion models: sensitivity analysis and inter-model comparison. J. Geophys. Res. 107, B9, 2179. doi:10.1029/2001JB000162.

Whipple KX. 2001. Fluvial landscape response time: how plausible is steady-state denundation? American Journal of Science 301: 313-325.

Whipple KX. 2004. Bedrock rivers and the geomorphology of active orogens. Annual Review of Earth and Planetary Sciences 32: 151-185.

Whipple KX, Tucker GE, 2002. Implications of sediment-flux dependent river incision models for landscape evolution. Journal of Geophysical Research 107(B2). doi:10.1029/2000JB000044.

Whipple KX, Hancock GS, Anderson RS, 2000. River incision into bedrock: Mechanics and relative efficacy of plucking, abrasion and cavitation, Geol. Soc. Am. Bull., 112: 490-503.

Whittaker, AC. 2012. How do landscapes record tectonics and climate? Lithosphere 4(2): $160-164$.

Whittaker AC, Boulton SJ. 2012. Tectonic and climatic controls on knickpoint retreat rates and landscape response times, Journal of Geophysical Research-Earth Surface 117: F02024. doi:10.1029/2011JF002157

Whittaker AC, Walker AS. 2015. Geomorphic constraints on fault throw rates and linkage times: Examples from the Northern Gulf of Evia, Greece. Journal of Geophysical Research: Earth Surface 120: 137-158. Doi: 10.1002/2014JF003318 
Whittaker AC, Cowie PA, Attal M, Tucker GE, Roberts G. 2007a. Bedrock channel adjustment to tectonic forcing: implications for predicting river incision rates. Geology 35: 103-106.

Whittaker AC., Cowie PA, Attal M, Tucker GE, Roberts G. 2007b. Contrasting transient and steady-state rivers crossing active normal faults: new field observations from the Central Apennines, Italy. Basin Research 19: 529-556. doi: 10.1111/j.1365-2117.2007.00337.

Whittaker AC, Attal M, Cowie PA, Tucker GE. Roberts G. 2008. Decoding temporal and spatial patterns of fault uplift using transient river long-profiles. Geomorphology. doi:10.1016/j.geomorph.2008.01.018.

Wobus CW, Whipple KX, Kirby E, Snyder N, Johnson J, Spyropolou K, Crosby B, Sheehan D. 2006a. Tectonics from topography: procedures, promise, pitfalls. In: Tectonics, Climate and Landscape Evolution. Willett, S., Hovius, N., Brandon, M., Fisher, D., (Eds.). AGU Special Paper 398; 55-74.

Wobus CW, Crosby BT, Whipple KX. 2006b. Hanging valleys in fluvial systems: Controls on occurrence and implications for landscape evolution. Journal of Geophysical Research: Earth Surface (2003-2012), 111(F2). 